\title{
Degradation of Solid Oxide Fuel Cell Anode in Phosphorus- containing Coal Syngas
}

Jinlong Yan

West Virginia University

Follow this and additional works at: https://researchrepository.wvu.edu/etd

\section{Recommended Citation}

Yan, Jinlong, "Degradation of Solid Oxide Fuel Cell Anode in Phosphorus-containing Coal Syngas" (2012). Graduate Theses, Dissertations, and Problem Reports. 4940.

https://researchrepository.wvu.edu/etd/4940

This Thesis is protected by copyright and/or related rights. It has been brought to you by the The Research Repository @ WVU with permission from the rights-holder(s). You are free to use this Thesis in any way that is permitted by the copyright and related rights legislation that applies to your use. For other uses you must obtain permission from the rights-holder(s) directly, unless additional rights are indicated by a Creative Commons license in the record and/ or on the work itself. This Thesis has been accepted for inclusion in WVU Graduate Theses, Dissertations, and Problem Reports collection by an authorized administrator of The Research Repository @ WVU. For more information, please contact researchrepository@mail.wvu.edu. 


\title{
Degradation of Solid Oxide Fuel Cell Anode in Phosphorus-containing Coal Syngas
}

\author{
Jinlong Yan
}

\author{
Thesis submitted to \\ The Benjamin M. Statler College of Engineering and Mineral Resources \\ at West Virginia University \\ in partial fulfillment of the requirements \\ for the degree of \\ Master of Science \\ in \\ Mechanical Engineering \\ Nianqiang Wu, Ph.D., Chair \\ Bruce Kang, Ph.D. \\ Ayyakkannu Manivannan, Ph.D. \\ Morgantown, West Virginia \\ 2012
}

Keywords: Solid Oxide Fuel Cell; Coal Syngas; Phosphorus; Impurity; Degradation Copyright 2012 Jinlong Yan 


\section{Abstract \\ Degradation of Solid Oxide Fuel Cell Anode in Phosphorus-containing Coal Syngas \\ Jinlong Yan}

Coal is the dominant energy for electric power generation. Solid oxide fuel cells (SOFCs) has been proposed to be incorporated into the coal based power plant. Currently, Nickel-Yttria stabilized Zirconia (YSZ) composite is widely used as the anode in SOFCs (YSZ as electrolyte) due to its low-cost, high electric conductivity, and excellent catalytic activity for many fuel types. However, the long-term stability of the Ni/YSZ anode remains a major concern when a SOFC is operated using coal syngas. Poisoning by the impurity species in the coal syngas poses severe threat on the SOFCs. Of all the impurities present in coal syngas phosphorus $(\mathrm{P})$ is the most detrimental. Therefore, it is vital to evaluate and unveil the underlying mechanism of phosphorus poisoning on the anode.

The present thesis deals with the influence of electric current and moisture concentration on the degradation of $\mathrm{Ni} / \mathrm{YSZ}$ anode upon exposure to $\mathrm{PH}_{3}$. Electrochemical testing has been carried out to evaluate the cell performance. In addition, the microstructure, elemental distribution, and chemical composition of the anodes are analyzed using various material characterization methods. Specifically, the behavior of Ni migration at the Ni/YSZ anode is quantitatively investigated. The nickel migration is induced by the electrostatic force due to electric current and by the chemical potential difference of phosphorus. In addition, cell degradation is accelerated by moisture in the $\mathrm{PH}_{3}$-containing fuel. 
To the parents who nurtured me.

To the teachers who inspired me.

To the friends who encouraged me. 


\section{Acknowledgements}

I would like to express my gratitude to my research adviser Dr. Nianqiang Wu for providing me the opportunity to do research under his guidance. Thank him for being a good advisor, a nice friend and for having so much help and patience on me. It was a great pleasure and valuable experience to work with him.

I would also like to thank Dr. Mingjia Zhi for his guidance on my research. He have taught me so many hands-on research skills and fostered me a good attitude upon research.

I am sincerely grateful to my committee members for their support and guidance on my research. I also wish to thank Savan Suri, Fanke Meng, Scott K. Cushing, and Dr. Xinqi Chen for their valuable time on this research work.

I am thankful to Dr. Weiqiang Ding, Ming Li, and Ting Chen for their help on XPS operation.

Special thanks to all members in Dr. Nianqiang Wu's group-Mingjia Zhi, Jiangtian Li, Rui Li, Honglei Gou, Ming Li, Fanke Meng, Scott K. Cushing, Chengcheng Xiang, Savan Suri, Anveeksh Koneru and Peng Zheng. It is all my pleasure to work with all the group members. It could not have been possible to complete my master study without their help and encouragement.

I also would like to thank the financial support from the US Department of Energy (DOE) EPSCoR Program under grant number DE-FG02-06ER46299. Dr Tim Fitzsimmons is the DOE Technical Monitor. Dr. R. Bajura is the Administrative Manager and Dr. I. Celik is the Technical Manager and Principle Investigator of this project. 


\section{Table of Contents}

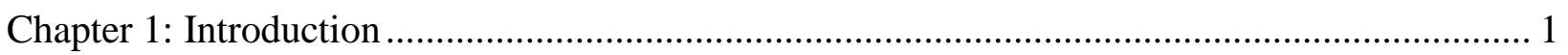

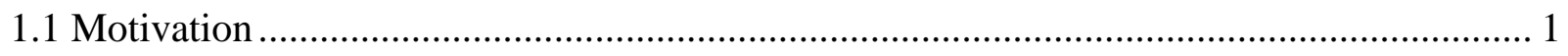

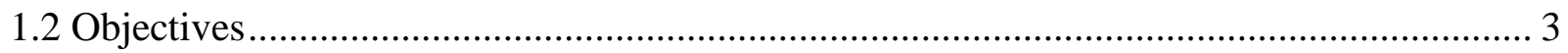

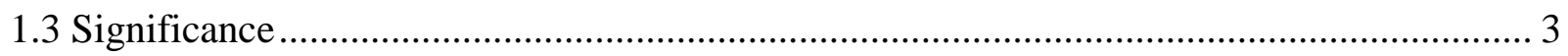

1.4 Thesis organization ...................................................................................................... 4

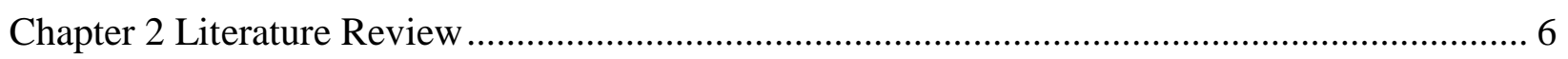

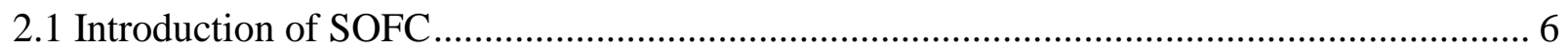

2.1.1 Operation of SOFC in coal-derived syngas ................................................................ 7

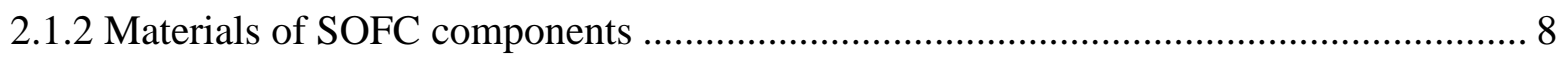

2.1.3 Practical SOFC efficiency ……………………........................................................... 11

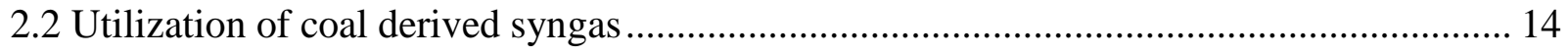

2.2.1 Power generation options from renewable energy and nuclear power.......................... 14

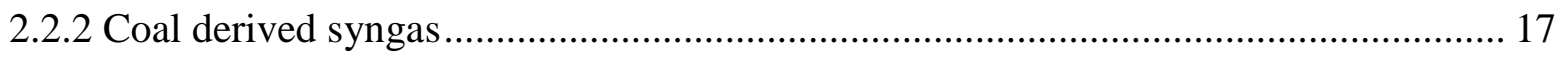

2.3 Overview of Ni/YSZ SOFC anode interactions with coal-syngas impurities...................... 19

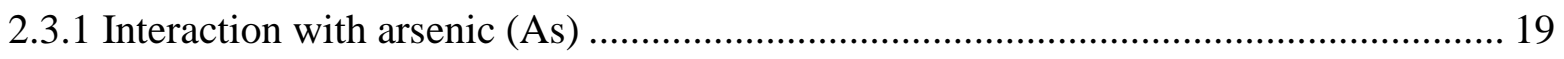

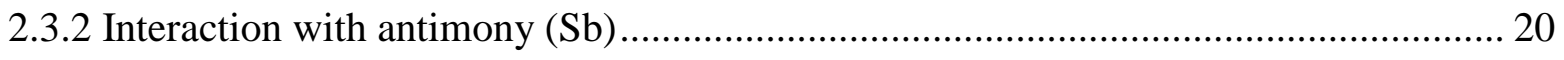

2.3.3 Interaction with selenium (Se).................................................................................... 20

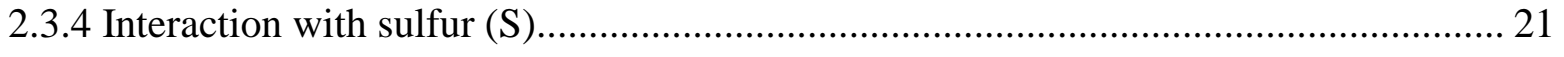

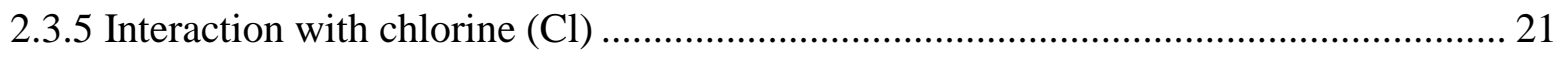

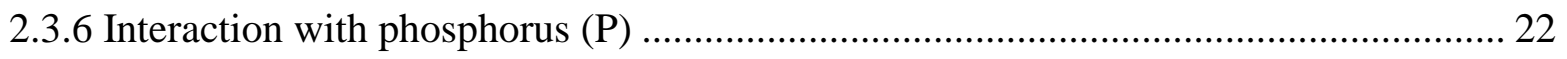

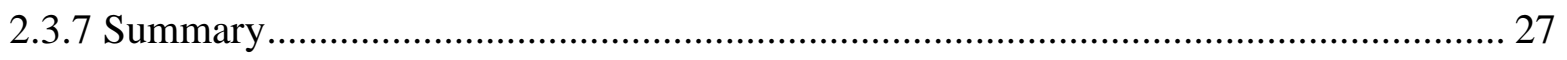

Chapter 3: Degradation Behavior and Mechanism of the Ni/YSZ Cermet SOFC Anode upon $\mathrm{PH}_{3}$

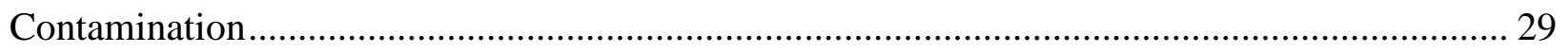




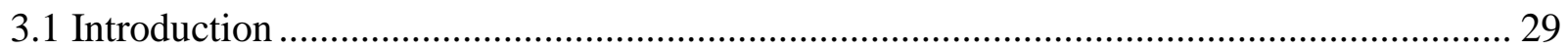

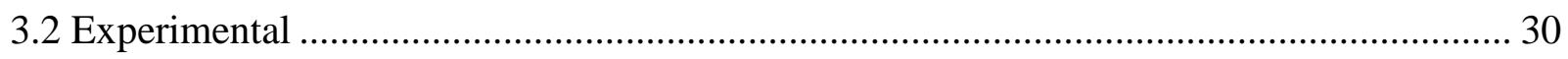

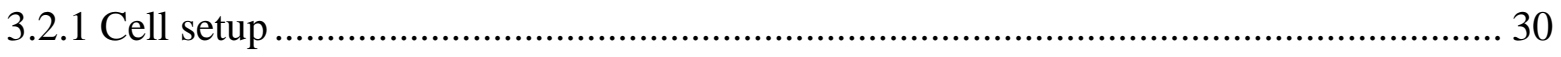

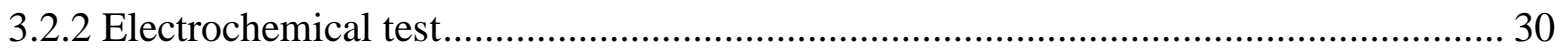

3.2.3 SEM/EDS characterization......................................................................... 31

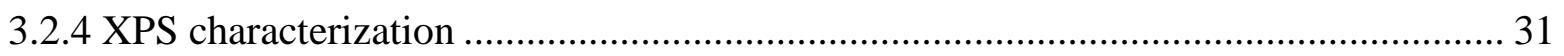

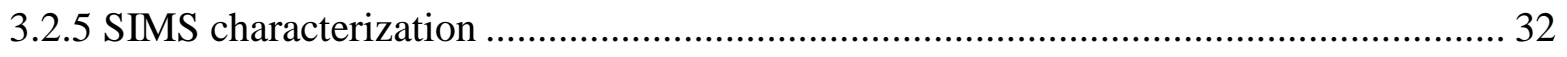

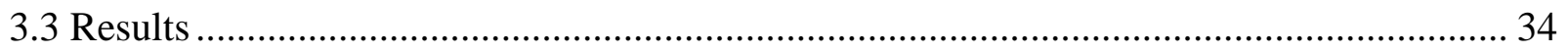

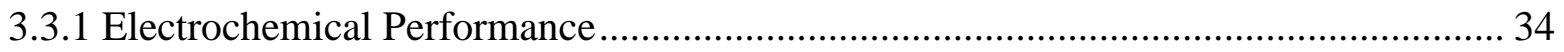

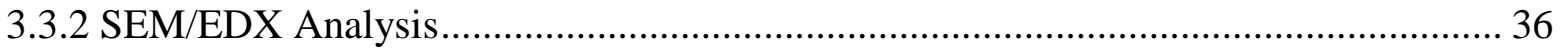

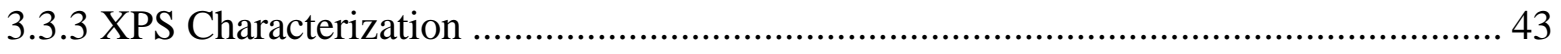

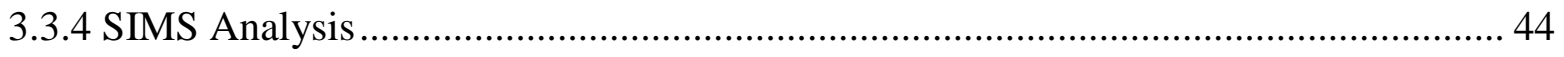

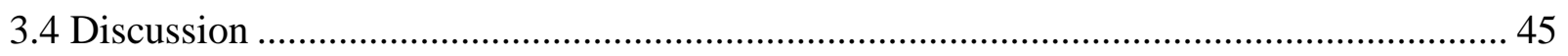

3.4.1 Influence of electric current........................................................................ 46

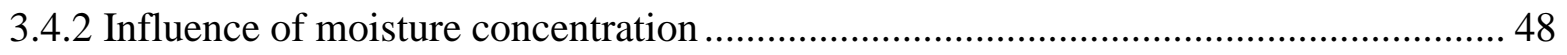

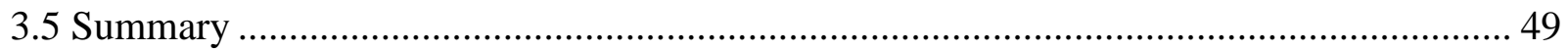

Chapter 4: Conclusions and Recommendations on Future Work ........................................... 50

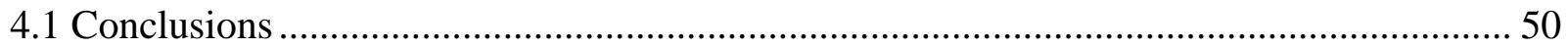

4.2 Recommendations for Future Work .................................................................. 50

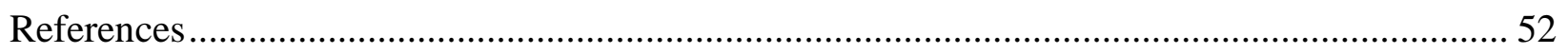




\section{List of Figures}

Figure 1.1 Schematic illustration of IGFC (Integrated gasification Fuel Cell) Plant and traditional coal combustion based power plant.

Figure 2.1 Schematic illustration of the operating principle of a solid oxide fuel cell in coal-derived syngas

Figure 2.2 Schematic illustration of coal consumption trends by major G20 consumers (\%/year) ${ }^{19}$

Figure 2.3 Two-dimensional chemical potential diagram for the Ni-P-O system in a log $\left\{\mathrm{p}\left(\mathrm{O}_{2}\right) / \mathrm{atm}\right\}$ vs. log $\mathrm{a}(\mathrm{P})$ plot at $800^{\circ} \mathrm{C}$. The isopartial pressure lines are displayed for $\mathrm{P}_{2}(\mathrm{~g}), \mathrm{P}_{4} \mathrm{O}_{9}$, and $\mathrm{P}_{4} \mathrm{O}_{10}$ at $10-6$ atm ${ }^{62}$.

Figure 3.1 Configuration for the structure of the anode half cell

Figure 3.2 Schematic illustration of the principle for time of flight-second ion mass spectroscopy (ToF-SIMS)

Figure 3.3 Nyquist plots of the impedance spectra taken from the half cells operated in $5 \mathrm{ppm} \mathrm{PH}_{3}$ contained coal-syngas at $800^{\circ} \mathrm{C}$ : (a) at current density of $0.25 \mathrm{~A} / \mathrm{cm}^{2}$ in wet coal-syngas, (b) without current load in wet coal-syngas.

Figure 3.4 Polarization impedance increases as a function of operation time (5 $\mathrm{ppm} \mathrm{PH}_{3}$ at $800^{\circ} \mathrm{C}$ ): at current density of $0.25 \mathrm{~A} / \mathrm{cm}^{2}$, without current load, and in dry coal-syngas, respectively.

Figure 3.5 SEM images of the Ni-YSZ anode surface after cell exposure to $\mathrm{PH}_{3}$ containing syngas at $800^{\circ} \mathrm{C}$ for:(a) 0 hour (clean cell) (b) 24 hours at current density of $0.25 \mathrm{~A} / \mathrm{cm}^{2}$ (c) 24 hours without current load (d) 24 hours with dry syngas.

Figure 3.6 SEM images of the Ni-YSZ anode surface after cell exposure to $\mathrm{PH}_{3}$ containing syngas $800{ }^{\circ} \mathrm{C}$ for 1 hour: (a) no current load (b) at current density of $0.25 \mathrm{~A} / \mathrm{cm}^{2}$; and 4 hours: (c) no current load (d) at current density of $0.25 \mathrm{~A} / \mathrm{cm}^{2}$.

Figure 3.7 Digital images after adjusting the contrast and brightness of the original SEM images collected from the surface of anode half-cell after exposure to $5 \mathrm{ppm} \mathrm{PH}_{3}$ for 24 hours at current density of $0.25 \mathrm{~A} / \mathrm{cm}^{2}$. 
Figure $3.8 \quad$ (a) (b) \& (c) are from one surface image of anode half cell after exposure to $5 \mathrm{ppm} \mathrm{PH}_{3}$ for 24 hours at current density of $0.25 \mathrm{~A} / \mathrm{cm}^{2}$ (a) original SEM image (b) after adjusting the image contrast and brightness (c) re-colored by using computer program (appendix A); (d) surface porosity as a function of operation time after cell exposure to $5 \mathrm{ppm} \mathrm{PH}_{3}$ at $800^{\circ} \mathrm{C}$.

Figure 3.9 Elemental maps collected during cross-sectional SEM analysis. $\mathrm{Ni}$ converted to Ni-P secondary phases in anode of electrolyte-supported cells by $5 \mathrm{ppm} \mathrm{PH}_{3}$ containing coal-syngas at $800{ }^{\circ} \mathrm{C}$ for 24 hours at current density of $0.25 \mathrm{~A} / \mathrm{cm}^{2}$. The top surface of the anode is shown at the left boundary in each image.

Figure 3.10 Elemental maps collected during cross-sectional SEM analysis. $\mathrm{Ni}$ converted to Ni-P secondary phases in anode of electrolyte-supported cells by 5 ppm $\mathrm{PH}_{3}$ containing coal-syngas at $800{ }^{\circ} \mathrm{C}$ for 24 hours without current load. The top surface of the anode is shown at the left boundary in each image.

Figure 3.11 Thickness of the top Ni-P compound layer compared to that of the whole anode layer as a function of time of anode half-cell upon exposure to $5 \mathrm{ppm} \mathrm{PH}_{3}$ containing coal-syngas at $800{ }^{\circ} \mathrm{C}$.

Figure 3.12 XPS spectra of (a) P 2p core level, (b) Ni 2pcore level (c) Zr 3d core level obtained from the surface of Ni/YSZ anodes after operation in various conditions.

Figure 3.13 SIMS images of the cross-section of Ni/YSZ anodes after operated in 5 ppm $\mathrm{PH}_{3}$ containing coal syngas for 24 hours at current density of 0.25 $\mathrm{A} / \mathrm{cm}^{2}$ : (a) with moisture, (b) without moisture.

Figure 3.14 SIMS line analysis of the cross-section of $\mathrm{Ni} / \mathrm{YSZ}$ anodes after operated in 5 ppm $\mathrm{PH}_{3}$ containing syngas for 24 hours: (a) at current density of $0.25 \mathrm{~A} / \mathrm{cm}^{2}$, (b) without current load. 


\section{List of Schematics}

Scheme 3.1 Procedures for anode half-cell test: (a) in dry and moisture containing coal syngas, (b) with and without current load. 


\section{List of Tables}

Table 2.1 World-Europe energy reserves and resources

Table2.2 Composition of typical coal-derived syngas ${ }^{21,22}$

Table2.3 Estimates of trace contaminant levels in coal-derived gas ${ }^{27}$

Table2.4 Summary of previous studies on the forms of Ni-P secondary phases after $\mathrm{Ni} / \mathrm{YSZ}$ anode exposure to $\mathrm{PH}_{3}$

Table2.5 SOFC performance degradation upon exposure to impurities of coal derived syngas

Table3.1 Melting points of substances involved in the anode contamination process 


\section{Chapter 1: Introduction}

\subsection{Motivation}

Coal is still a dominant fuel source due to its abundance worldwide. However, the air pollution produced by the direct combustion of coal remains a serious problem. Traditional coal combustion could be replaced by the highly efficient Integrated Gasification Combined Cycle (IGCC) (Figure 1.1). The increased efficiency in IGCC comes from solid oxide fuel cells (SOFCs) utilizing coal-derived syngas (CSG). SOFCs manage to greatly improve the power generation efficiency while reducing operating costs and emissions compared to modern power generation techniques. SOFCs also co-produce other commercially useful commodities such as hydrogen. The efficiency of coal-syngas fueled SOFCs is greater than $50 \%$ as compared to $30-40 \%$ in traditional coal combustion based power plants. In addition,

combined heat-and-power systems based on SOFCs are able to reduce $\mathrm{CO}_{2}$ emission by $50 \%{ }^{1}$. SOFCs compatible with coal or coal derived fuel gases will act as a driving force in the power generation industry securing the growing energy needs of the global market. 


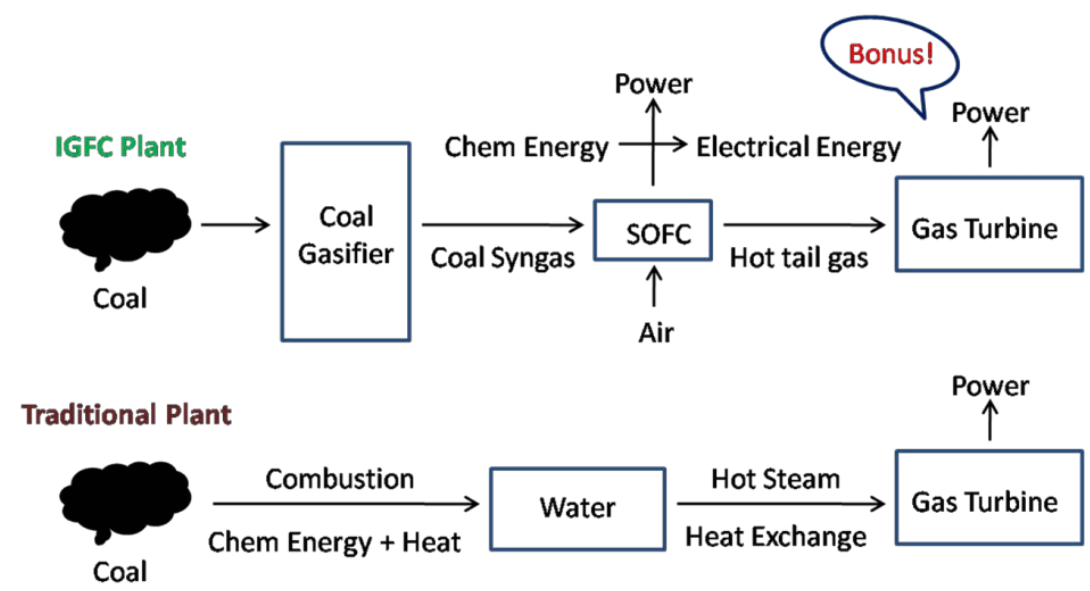

Figure 1.1 Schematic illustration of IGFC (Integrated Gasification Fuel Cell) Plant and traditional coal combustion based power plant.

The major barrier to implementation of SOFCs in IGFC for power generation is degradation of the anode material by the impurities in coal syngas. Coal syngas commonly contains impurities such as arsenic, antimony, chlorine, cadmium, selenium and phosphorus. These impurities react with the anode of the SOFC, impacting cell performance and causing severe losses in the power generation efficiency ${ }^{2}$. Phosphorus (P) is prevalent in coal syngas in the form of phosphine and has been shown to be the most detrimental impurity to a SOFCs performance. ${ }^{3}$ It is vital to evaluate and understand the process by which phosphorus degrades SOFC performance if IGCC power plants are to be utilized to meet current energy needs.

Phosphorus poisoning in Nickel-Yttria stabilized Zirconia (Ni/YSZ) anodes has been investigated. Previous studies on phosphorus poisoning dealt with the influence of temperature, $\mathrm{PH}_{3}$ concentration, electric current and moisture on the production of the nickel-phosphorus secondary phase. Cell degradation caused by $\mathrm{PH}_{3}$ contamination can be attributed to loss of $\mathrm{Ni}$ at the triple phase boundary (TPB) caused by material migration and the production of the Ni-P secondary phase ${ }^{4}$. Material migration is mainly the result of concentration and temperature gradients, mechanical stress, and the electric field present in the cell ${ }^{4}$. Electromigration, the migration of material due to the electric field, has been suggested as the primary reason for Ni migration and re-distribution ${ }^{5}$. As well the Ni-P secondary phase 
results in a decrease of catalytic Ni sites, blockage of gas diffusion channels, and loss of charge transport pathways ${ }^{6}$.

However, the degradation mechanism is poorly understood. The process of Ni re-distribution is still unclear during material migration and discrepancies exist in the exact form of Ni-P secondary phase formation when the anode is poisoned by phosphorus. The motivation for this thesis is (1) to make the direct utilization of coal derived syngas in solid oxide fuel cell feasible in commercial power production, and (2) to clarify the mechanism of anode degradation due to phosphorus impurities contained in the coal syngas.

\subsection{Objectives}

The overall objective of this thesis is to study the degradation mechanism of Ni/YSZ anodes upon $\mathrm{PH}_{3}$ contamination. In order to achieve this objective, the following specific aims will be pursued.

(1) Investigate the influence of electric current on Ni/YSZ anode degradation due to $\mathrm{PH}_{3}$ poisoning. $\mathrm{Ni} / Y S Z$ anode half cells will be investigated with and without a current load to understand the effects of the electric current and the chemical potential on the Ni redistribution mechanism. In addition, the forms of Ni-P secondary phase will be determined after the Ni/YSZ anode is exposed to $\mathrm{PH}_{3}$ containing syngas.

(2) Study the influence of moisture concentration on the degradation of cell performance due to $\mathbf{P H}_{3}$

The degradation in Ni/YSZ anode performance will be investigated for the anode half cells operated in both moisture-containing and moisture-free coal syngas. The change in microstructure of the anode materials will be measured to determine the chemical composition of Ni-P secondary phases after $\mathrm{PH}_{3}$ poisoning.

\subsection{Significance}


SOFCs compatible with coal or coal derived fuel gases are key components is integrated gasification combined cycle (IGCC) systems. Ni/YSZ is the most commonly used anode material for SOFCs. However its long term stability in coal-syngas is still the major barrier to commercialization. The results will show the Ni/YSZ anode degradation behavior and gain better understanding of the mechanism responsible for poisoning by phosphorus. This investigation is expected to give guidance to industry to eliminate phosphine in coal syngas fueled SOFC application. Specifically this thesis will have a significant impact on:

(1) Determining the exact forms of Ni-P secondary phases after cell exposure to $\mathrm{PH}_{3}$. This information will provide an experimental basis for theoretical studies on the kinetics of phosphorus diffusion in the anode and the reaction rates involved in the phosphorus contamination process.

(2) Determining a more exact relationship between the cell electrochemical performance and the materials microstructure by the quantitative study of Ni migration behavior at the Ni/YSZ anode. In addition, it is a significant attempt to kinetically explore the mechanism of cell degradation caused by phosphine poisoning.

\subsection{Thesis organization}

In this thesis we focus on the influences of the current density and the moisture concentration on the degradation behavior of Ni/YSZ cermet SOFC anodes upon $\mathrm{PH}_{3}$ poisoning. Theoretical and experimental techniques are combined to gain an underlying mechanistic insight into the effects of electric current and moisture concentration on the anode degradation. This thesis is divided into four chapters.

- Chapter 1 introduces the background of this research topic including the motivation, objectives and significance of the project.

- Chapter 2 presents a literature review for coal-derived syngas fueled SOFCs and the interaction of a variety of impurities contained in coal-syngas with Ni/YSZ anodes. 
- Chapter 3 performs a fundamental study on the contribution of electric current and moisture concentration on Ni/YSZ SOFC anode degradation due to $\mathrm{PH}_{3}$ poisoning.

- Chapter 4 summarizes the thesis and focuses on the primary conclusions, as well as discussing future studies motivated by this work. 


\section{Chapter 2 Literature Review}

\subsection{Introduction of SOFC}

A fuel cell is a device that directly converts chemical free enthalpy into electrical energy by combining fuel gases and oxygen to produce water and/or carbon dioxide and heat. Conventional energy production schemes go through multiple energy conversion processes such as burning fuel to produce heat, transforming heat to mechanical energy, and converting mechanical energy to electrical power. Fuel cells do not require multiple conversion processes and therefore exhibit a higher energy conversion efficiency (up to 70\% in pressurized hybrid system and 40-60\% unassisted) compared to modern thermal power plants (30-40\% efficient). In addition, the byproducts generated by fuel cells are more environmentally friendly than fossil fuels. In fuel cells hydrogen is the primary gaseous fuel. Hydrogen is utilized by fuel cells in the following main designs: Alkaline Fuel Cells (AFC), Phosphoric Acid Fuel Cells (PAFC), Proton Exchange Membrane Fuel Cells (PEMFC), Molten Carbonate Fuel Cells (MCFC), and Solid Oxide Fuel Cells (SOFC). SOFCs show the most potential for commercialization due to the following advantages ${ }^{7}$.

- Less electrolyte management is needed due to the solid state structure;

- Very high efficiencies are achieved, reaching 80\% in hybrid configurations;

- The anode is not sensitive to $\mathrm{CO}$, and $\mathrm{CO}$ produced during fuel reformation can be used as a fuel;

- Dehydration degradation is not an issue due to the anodes participation in the water-gas shift reaction;

- Combined heat and power applications produce high-grade waste heat;

- Internal reforming of hydrocarbon fuels leads to fuel flexibility; 
- The interconnection and balance of the plant requires inexpensive construction materials.

Fuel flexibility is the distinguishing property when comparing SOFC to other potential clean energy devices. SOFCs are capable of using various gases as a fuel source such as $\mathrm{H}_{2}{ }^{8}$, natural gas ${ }^{9}$, biogas ${ }^{10}$, and coal derived syngas ${ }^{11}$. The direct utilization of coal derived syngas enables us to increase energy efficiency, reduce operation cost, and co-produce other marketable commodities such as hydrogen and sulfur from a prevalent energy source.

The study of SOFCs began when Nernst demonstrated in 1899 the ionic conductivity of solid-state Yttria-stabilized Zirconia (YSZ) ${ }^{12}$. However, various technical challenges prevent the development of practical SOFC applications. In recent years, SOFC studies have focused on the minimization of electrolyte resistance, the development of compatible anodes and cathodes, the reduction of operating temperature, and the design of cost-effective fabrication methods ${ }^{13}$.

SOFCs present a more efficient way to generate electricity from fossil fuels without having to change the current infrastructure. Moreover, SOFC that can operate on fossil fuels is able to bring itself to the market sooner without waiting for cleaner fuels to be available.

\subsubsection{Operation of SOFC in coal-derived syngas}

For a coal-syngas fed SOFC, the fuel $\left(\mathrm{H}_{2}\right.$ and $\mathrm{CO}$ ) is supplied to the anode and an oxidant (air or oxygen) is supplied to the cathode in a continuous cycle. A dense oxygen-ion conducting electrolyte is used to separate the two gases. As seen in Figure 2.1, during operation at high temperatures (700 900 $\left.{ }^{\circ} \mathrm{C}\right)$ the following electrochemical reactions occur:

$$
\begin{array}{ll}
\text { Anode: } & \mathrm{H}_{2}+\mathrm{CO}+2 \mathrm{O}^{2-} \rightarrow \mathrm{H}_{2} \mathrm{O}+\mathrm{CO}_{2}+4 \mathrm{e}^{-} \\
\text {Cathode: } & \mathrm{O}_{2}+4 \mathrm{e}^{-} \rightarrow 2 \mathrm{O}^{2-} \\
\text { Overall: } & \mathrm{H}_{2}+\mathrm{CO}+\mathrm{O}_{2} \rightarrow \mathrm{H}_{2} \mathrm{O}+\mathrm{CO}_{2}
\end{array}
$$




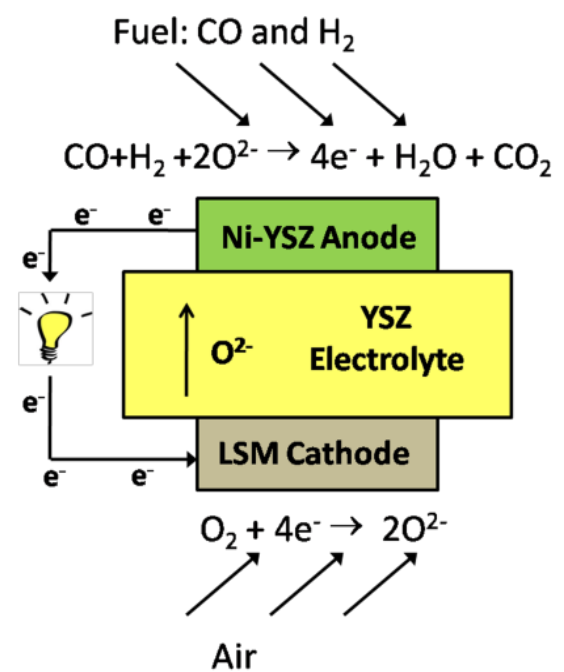

Figure 2.1 Schematic illustration of the operating principle of a solid oxide fuel cell in coal-derived syngas

Thermodynamics can be used to predict the probability of the reactions in a SOFC spontaneously proceeding. Thermodynamics can also be used to calculate a theoretical upper boundary on the electric potential that can be generated by a SOFC. The Nernst equation predicts the reversible cell voltage as a function of the concentration and/or pressure of the reactant and product species ${ }^{13}$

$$
\mathrm{E}=\mathrm{E}^{\circ}-\frac{\mathrm{RT}}{\mathrm{nF}} \ln \frac{\mathrm{aH}_{2} \mathrm{O} \cdot \mathrm{aCO}_{2}}{\mathrm{a}_{\mathrm{H}} \cdot \mathrm{aCO} \cdot \mathrm{aO}_{2}}
$$

In this equation, $\mathrm{E}^{\circ}$ is the standard-state reversible voltage, $\mathrm{F}$ is Faraday’s constant (96485 C/electrons), $\mathrm{T}$ is absolute temperature $(\mathrm{K}), \mathrm{n}$ is the number of electrons, $\mathrm{R}$ is gas constant $(\approx 8.314 \mathrm{~J} / \mathrm{mol} \cdot \mathrm{K})$, and a is activity of the species involved in the cell reaction.

\subsubsection{Materials of SOFC components}

Modern SOFC studies have mainly dealt with minimizing the electrolyte resistance, development of new cell materials, reducing operating temperature, and designing cost-effective fabrication methods ${ }^{13}$. The composition and structure of materials play a significant role in the performance of the SOFC. The material used for the electrolyte, cathode, and anode must all be designed to meet their specific needs. 


\section{Electrolyte}

SOFCs are based on crystalline oxide ceramic electrolyte materials that conduct oxygen ions via a defect hopping mechanism. Various candidate SOFC electrolyte materials exist, with the two most common choices being yttria-stabilized zirconia (YSZ) and gadolinium-doped ceria (GDC). YSZ is currently the most widely used electrolyte material for SOFCs. Two zirconium cations $\left(\mathrm{Zr}^{4+}\right)$ are replaced by two yttrium $\left(\mathrm{Y}^{3+}\right)$ cations in the fluorite crystal structure of YSZ. One oxygen site $\left(\mathrm{O}^{2-}\right)$ is left vacant in order to maintain charge equilibrium. The ionic conductivity is influenced by doping concentration, temperature, atmosphere, grain size, and aging time. Doped ceria is also an oxygen-ion-conducting ceramic material with a fluorite structure. In the case of gadolinium-doped ceria (GDC), doping and host ions are very close in size leading to a higher ionic conductivity.

\section{Cathode}

Modern studies on cathode materials mainly focus on maximizing the number of triple-phase boundary (TPB) sites. At TPB sites the electrolyte, oxygen, and electrode meet allowing the electrochemical reactions necessary for the operation of the SOFC. In YSZ-based SOFCs the dominant cathode material is strontium-doped $\mathrm{LaMnO}_{3}$ perovskite, or LSM. The incorporation of the divalent dopant $\mathrm{Sr}^{2+}$ into lanthanum manganite under oxidizing conditions produces $\mathrm{Mn}^{4+}$ species, resulting in high electronic conductivity via electron transfer by the process $\mathrm{Mn}^{3^{+}} \rightarrow \mathrm{Mn}^{4+}+e^{-}$. The composition and structure of the cathode materials plays a very important role in the performance of the solid oxide fuel cell. SOFC cathodes must be highly active towards the electrochemical reduction of oxygen. Thus, the material must have oxygen-ionic conductivity, electronic conductivity, and electrochemical catalytic activity. Two techniques are used to construct cathodes in SOFCs: composite electrodes which are a mixture of a solid electrolyte and an electronic conductor such as LSCF/GDC (usually the composite of $\mathrm{La}_{0.6} \mathrm{Sr}_{0.4} \mathrm{Co}_{0.2} \mathrm{Fe}_{0.8} \mathrm{O}_{3}$ and $\mathrm{Ce}_{0.8} \mathrm{Gd}_{0.2} \mathrm{O}_{2}$ ) and LSCM/YSZ (usually the composite of $\mathrm{La}_{0.6} \mathrm{Sr}_{0.4} \mathrm{Co}_{0.2} \mathrm{MnO}_{3}$ and $\mathrm{Zr}_{0.08} \mathrm{Y}_{0.92} \mathrm{O}_{2}$ ) or by using mixed ionic electronic conductors (MIEC) ${ }^{14}$ such as LSM and LSCF. 


\section{Anode}

SOFC electrodes must support highly active electro-chemical reactions under high-temperature environments. The electrode materials should have must maintain chemical and thermal stability under these conditions. Generally, the required properties of SOFC electrodes are:

- High electrical conductivity and high electro-catalytic activity.

- Compatibility with adjacent cell components, such as electrolyte and interconnects. There should be negligible chemical reactions between the electrodes and the electrolyte or interconnect components. The thermal expansion coefficient should also match among materials match.

- Sufficient porosity to allow gas diffusion (fuel gas in anode, and oxygen or air in cathode).

- Fuel flexibility. SOFCs are capable of utilizing many fuel types such as $\mathrm{H}_{2}{ }^{8}$, natural gas ${ }^{9}$, oil ${ }^{10}$, biogas $^{11}$, and coal derived syngas ${ }^{12}$. The anode material must be tolerant to carbon deposition and trace impurities especially when operated with hydrocarbon fuels.

- Stability. The anode must show long-term stability. The Solid State Energy Conversion Alliance (SECA) targeted duration time for SOFCs fueled by coal-syngas in 2011 is 1500 hours with a degradation of less than $2 \%$.

- Low cost. To compete with the traditional electric power generation, SOFC costs must meet the market demand.

The motivation to use coal-syngas as a fuel in SOFCs has lead to active efforts to evaluate anode materials that can maintain performance in moisture, suppress carbon deposition, and withstand contamination from the trace impurities contained in coal-syngas. One widely used anode material is $\mathrm{Ni}$ YSZ cermet. In Ni-YSZ anodes, the Ni provides the electronic conductivity and catalytic activity while the YSZ builds a structural framework. The YSZ also offers improved thermal expansion matching and plays an inhibitor for coarsening of the Ni phase during consolidation and operation. YSZ provides ionic conductivity to the electrode effectively broadening the triple-phase boundaries (TPBs). The advantages of Ni/YSZ over other materials are its high electronic conductivity, excellent activity for diverse reformed 
fuels, chemical and physical compatibility with YSZ electrolytes, and relatively low cost. However, $\mathrm{Ni}$ /YSZ also has disadvantages such as sintering and agglomeration at high temperature, sensitivity to oxygen, high activity of the nickel catalyst towards steam reforming, coking in hydrocarbons containing fuel gases, and easy poisoning by impurity species (sulfur, phosphorus, arsenic, selenium, etc.).

\subsubsection{Practical SOFC efficiency}

The efficiency of a SOFC must always be less than the reversible thermodynamic efficiency. Degradation of SOFC efficiency mainly results from fuel utilization losses and voltage losses.

Fuel utilization losses arise in the cell installation process. Voltage losses come from a series of factors: activation polarization, concentration polarization, and ohmic loss. The actual voltage output from a SOFC can be represented as ${ }^{13}$

$$
\mathrm{V}=\mathrm{E}-\eta_{\text {act }}-\eta_{\text {ohmic }}-\eta_{\text {conc }}
$$

where $\mathrm{E}$ is the thermodynamic equilibrium open-circuit potential of the cell calculated from Nernst equation, $\eta_{\text {ohmic }}$ is the ohmic loss from both ionic and electronic conduction of the cell system, $\eta_{\text {act }}$ is the activation loss due to reaction kinetics, and $\eta_{\text {conc }}$ is the concentration loss related to mass transport.

\section{Activation polarization}

The activation overpotential for an electrode is defined as

$$
\eta_{\text {act }}=\left(\Phi_{\mathrm{e}}-\Phi_{\mathrm{i}}\right)-\left(\Phi_{\mathrm{e}}-\Phi_{\mathrm{i}}\right)_{\mathrm{eq}}
$$

where $\Phi_{\mathrm{e}}$ and $\Phi_{\mathrm{i}}$ are the electric potential of the electronic-conduction phase (electrode) and ionicconduction phase (electrolyte), respectively. The subscript eq denotes the equilibrium state. The potential difference at equilibrium is actually the reversible potential of an electrode, i.e. $\left(\Phi_{\mathrm{e}}-\Phi_{\mathrm{i}}\right)_{\mathrm{eq}}=\mathrm{E}_{\mathrm{rev}}$.

At equilibrium the net current for the coal-syngas fueled SOFC is given by Butler-Volmer equation ${ }^{13}$

$$
j=j_{0}\left(e^{\frac{n \alpha w \eta}{\mathrm{RT}}}-e^{\frac{-n[1-\alpha g \mu \eta}{\mathrm{RT}}}\right)
$$

where $j$ is net current density, $j_{0}$ represents exchange current density for the reaction at dynamic equilibrium, and $\alpha$ is transfer coefficient which expresses the interfacial electrical potential influences on 
the forward to reverse activation barrier. The activation overvoltage $\eta$ indicates the voltage lost in overcoming the energy barrier for the electrochemical reaction. The Butler-Volmer equation is of great importance in electrochemical kinetics since it shows that the net current yielded in an electrochemical reaction increases with the activation overvoltage.

For a fixed electrochemical reaction involved in a fuel cell system, it is clear that we cannot significantly change $\mathrm{n}, \alpha$, F, or $\mathrm{R}$ in Butler-Volmer equation. Thus to improve the kinetic performance of a fuel cell we should focus on increasing $j_{0}$. The exchange current density $j_{0}$ is further expressed as ${ }^{13}$

$$
j_{0}=2 F c_{R}^{*} f e^{\frac{-\Delta G_{1}^{q}}{R T}}
$$

where $c_{R}^{*}$ is reactant surface concentration $\left(\mathrm{mol} / \mathrm{cm}^{2}\right), \Delta G_{1}^{\emptyset}$ is activation barrier, and $f$ is the decay rate to products. The decay rate to products depends on the lifetime of an activated reactant and the probability of the forward reaction taking place. $f$ shows no obvious change for a known electrochemical reaction, therefore the dominant parameters that effect the kinetic performance of a fuel cell are $c_{R}^{*}, \Delta G_{1}^{\emptyset}$ and $\mathrm{T}$. I0can be increased by:

1. Increasing the surface concentration of reactants $c_{R}^{*}$. To prevent $c_{R}^{*}$ from being the limiting step in the reaction the surface concentration must be higher than the rate of forward reaction.

2. Decrease the activation barrier $\Delta G_{1}^{\emptyset}$. The variation of $\Delta G_{1}^{\emptyset}$ will exponentially affect the size of $j_{0}$. Selecting a proper catalyst for the electrochemical reaction can dramatically decrease the activation barrier $\Delta G_{1}^{\emptyset}$.

3. Increase the temperature $\mathrm{T}$. Raising the temperature of the system increases the vibrational internal energy of the system which increases the rate of collisions between molecules. Increased collisions leads to an increase in the probability of a reactant overcoming the potential barrier necessary for the forward reaction to take place.

Analysis of the parameter space gives guidance to optimizing the SOFC. In practical applications other factors may also influence the activation polarization. 
1. Reaction mechanism. The more complex intermediate steps in the electrochemical reaction the more chemical bonds must be broken and the larger the energy barrier.

2. Operating conditions. Thermodynamic operating parameters such as gas pressure can affect the activation of chemical and electrochemical reactions similar to temperature.

3. Catalyst microstructure. The higher the density of triple-phase boundary (TPB) sites where the electrolyte, oxygen and electrode meet the higher the performance of the SOFC.

4. Trace impurities. Minor and trace components in fueled coal-derived syngas deteriorate the anode materials and degrade the electrochemical performance of the cell. The poisonous species in coal syngas include arsenic, selenium, sulfur, antimony, phosphorus and hydrogen chloride. For example, the adsorption of antimony at the active interface of $\mathrm{Ni} / \mathrm{YSZ}$ causes electronic percolation losses by forming secondary phases like $\mathrm{Ni}_{3} \mathrm{Sb}, \mathrm{Ni}_{5} \mathrm{Sb}_{2}$ and $\mathrm{NiSb}$. Phosphine also has been demonstrated to poison the Ni/YSZ anode by converting Ni to Ni-P secondary phases. The reduction of TPB and Ni catalytic sites is proposed to cause cell degradation by phosphine poisoning.

\section{Ohmic polarization}

The ohmic loss $\eta_{\text {ohmic }}$ through the fuel cell obeys Ohm's law resulting in a nearly linear behavior. The ohmic polarization can be written as ${ }^{13}$

$$
\eta_{\text {ohmic }}=j A\left(\sum_{k=1}^{n} R_{k}\right)
$$

where $R_{k}$ represents the area-specific resistance (ASR) of the individual cell components. The ohmic polarization mainly originates in the process of ionic conduction in the electrolyte. The ionic conductivity in ceramic electrolytes is usually four to eight orders of magnitude lower than the electric conductivity in metallic electrodes. To minimize the ohmic loss the electrolytes must be manufactured as thin as possible.

\section{Concentration polarization}


Concentration polarization originates in poor mass transport. Mass transport in fuel cell electrodes is mainly by diffusion. The overpotential created by concentration loss is given as ${ }^{13}$

$$
\eta_{\text {cone }}=\frac{R T}{n F} \ln \frac{j L}{j_{L}-j}
$$

where $i_{L}$ represents the limiting current density and is defined as

$$
j_{L}=n F D^{\mathrm{eff}} \frac{c_{R}^{\circ}}{\delta}
$$

Where $D^{\text {eff }}$ is the effective diffusivity within the catalyst layer ( $D^{\text {eff }}$ corrects the gas molecular diffusion flux impeded by blockage in pore walls), $c_{R}^{0}$ is the reactant concentration in the flow channel, and $\delta$ is the electrode thickness. The average diffusion coefficient of an uncharged species is determined by the following factors:

- The partial pressure of the species. Higher pressure leads to a greater number of collisions between molecules and increases the average diffusion rate.

- The molecules velocity, which is a function of temperature of the system.

- The size and mass of molecules. Molecular size has an influence on the collision cross section and the molecular weight affects motion after collisions.

\subsection{Utilization of coal derived syngas}

\subsubsection{Power generation options from renewable energy and nuclear power}

Clean, alternative energy resources must be explored to solve the exponentially growing energy need without increasing environmental damage. Current renewable energy sources are: hydropower (14,000 TWh), wind power (167,000 TWh), solar energy (444,000 TWh), biomass (70,000 TWh), geothermal

energy (139,000 TWh), and ocean energy 1 EJ (280 TWh) ${ }^{15}$. The current global nuclear power capacity is 377,000 MW. Compared to their huge energy capacities, problems also exist for the individual power sources. 
Hydro Power. Hydropower has been employed worldwide with commercial success, however environmental problems such as $\mathrm{CO}_{2}$ release due to submerged vegetation and damage to the surrounding ecosystem is still a major concern. Moreover, the difficulty of finding efficient hydro sites plagues deployment of this technology in many countries.

Wind Power. Wind power is the most developed technology and competitive commercial product due to renewability and low-cost. Government tax credits have accelerated the development of wind power systems. However, this technology is still plagued by low energy density and its intermittent nature.

Solar Power. Solar energy is the most promising renewable resource due to the vast reserve of energy located in the sun, but the technology is currently expensive preventing large scale deployment.

Biomass Power. Biomass power is not entirely carbon free but carbon circulation in the bio-circle resonates well with environmentalists. The most significant drawback for large-scale commercialization of biomass is its low energy efficiency and energy density. New technologies need to be developed to improve biomass’s economics and efficiency.

Nuclear Power. Nuclear technology is utilized as a major power generation method in many countries, such as Japan, France, and the United States. However public safety concerns limit large scale deployment.

Table 2.1 lists the most common energy resources in Europe and around the world. Coal is still a major source of energy due to its abundant reserves and existing infrastructure. For example, the U.S. produces over $50 \%$ of its power from coal ${ }^{16,17}$.

Table 2.1 World-Europe energy reserves and resources ${ }^{18}$

\begin{tabular}{cccccc}
\hline & $\begin{array}{c}\text { Reserves } \\
{[\mathrm{EJ}]}\end{array}$ & $\begin{array}{c}\text { Resources } \\
{[\mathrm{EJ}]}\end{array}$ & $\begin{array}{c}\text { Total } \\
\text { Recoverable } \\
\text { World [EJ] }\end{array}$ & $\begin{array}{c}\text { Fraction } \\
\text { of use } \\
\text { in Europe [EJ] }\end{array}$ & $\begin{array}{c}\text { Total } \\
\text { Recoverable } \\
\text { Europe [EJ] }\end{array}$ \\
\hline Conventional oil & 6360 & 3515 & 8821 & 0.07 & 617 \\
Unconventional oil & 2761 & 10460 & 7991 & 0.07 & 559 \\
\hline Conventional gas & 5109 & 6886 & 9929 & 0.07 & 695
\end{tabular}




\begin{tabular}{cccccc} 
Unconventional gas & 63 & 48633 & 24390 & 0.07 & 1707 \\
\hline Coal & 17668 & 103898 & 69617 & 0.07 & 4873 \\
Lignite & 1963 & 12218 & 10516 & 0.07 & 736 \\
\hline Uran & 644 & 2139 & 2141 & 0.40 & 857 \\
Thorium & 908 & 964 & 1583 & 0.07 & 111 \\
\hline Sum & 35476 & 188731 & 134977 & 0.96 & 10155 \\
\hline
\end{tabular}

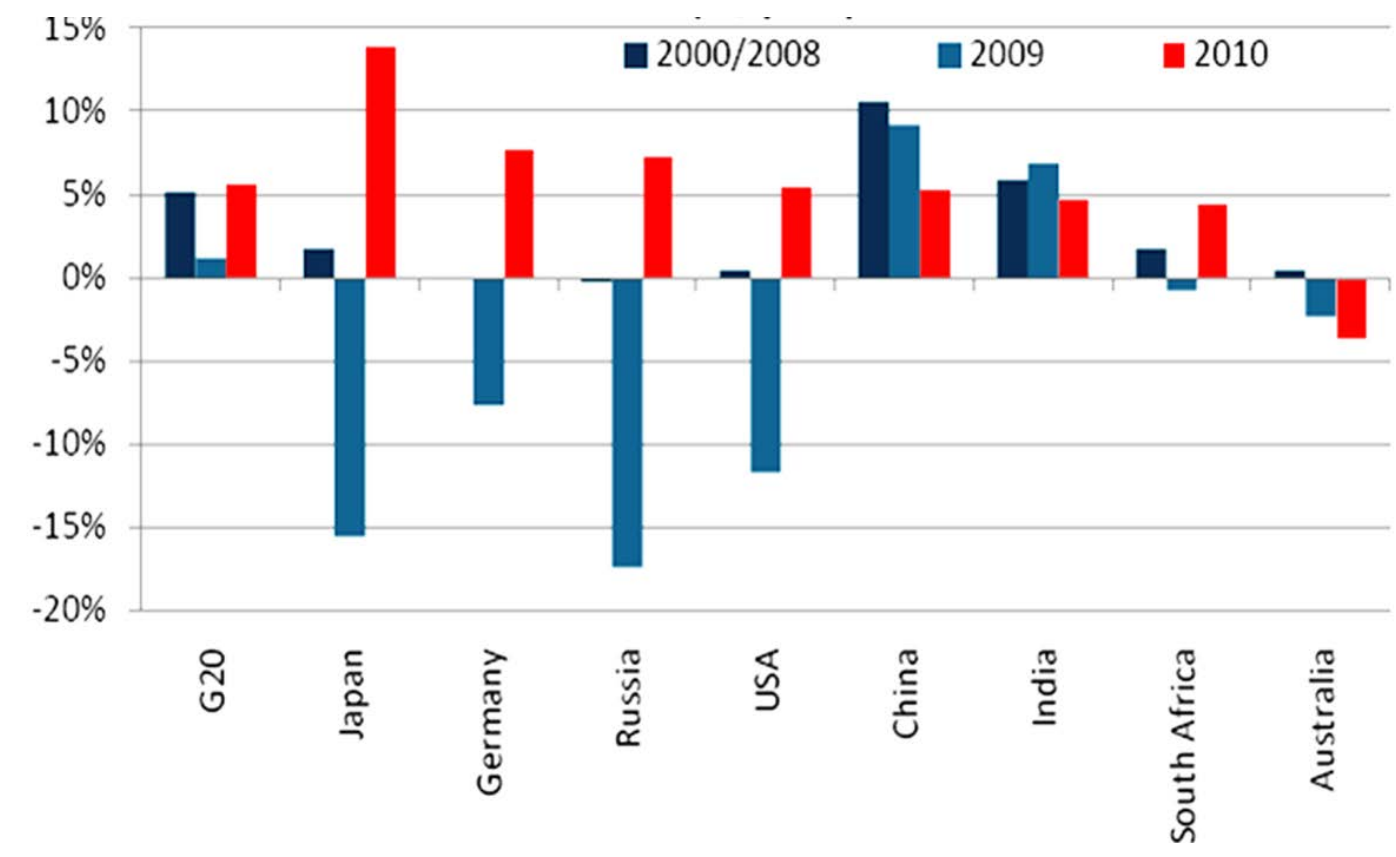

Figure 2.2 Schematic illustration of coal consumption trends in major G20 consumers (\%/year) ${ }^{19}$

Figure 2.2 indicates the fast rise of coal demand in 2010 in G20 countries following a collapse in the market due to economic depression in 2009.

The use of coal over natural gas has a significant role in the long-term stabilization of energy prices. Typically, the cost of natural gas is $2 \sim 3$ times higher than the cost of coal. It is thus expected that in the next 25 to 50 years clean coal will continue to be a major energy source in the world market.

The conventional utilization of coal is through burning of coal to produce heat, transforming heat to mechanical energy and converting to electrical power. This cycle has limited energy conversion efficiency (30-40\%). Therefore, new coal utilization technologies must be developed to improve the 
energy conversion efficiency. One practical solution is to convert coal to hydrogen and carbon monoxide. The traditional coal gasification technologies include Chevron-Texaco’s process, Global Energy’s E-Gas, GTI’s UGas process, and Westinghouse Plasma’s system.

\subsubsection{Coal derived syngas}

Coal is a potent resource for providing fuel gases for fuel-cell based distributed power generation. When coal-derived syngas (CSG) is directly utilized as the fuel for Solid Oxide Fuel Cells (SOFCs), it is capable of increasing energy efficiency, reducing operating costs, and co-producing other commercially useful commodities such as hydrogen. CSG is produced by coal gasification in which coal is mixed with an oxidant (oxygen or air) and steam at $500 \sim 800^{\circ} \mathrm{C}$ and pressures of $24 \sim 70 \mathrm{~atm}^{20}$.

\section{Coal-syngas composition}

Steam reforming technology is a suitable economic alternative to conventional gasification methods. The involved chemical reactions are:

$$
\begin{aligned}
& \text { Pyrolysis Coal } \rightarrow \mathrm{CO}+\mathrm{CO}_{2}+\mathrm{H}_{2}+\mathrm{H}_{2} \mathrm{O}+\mathrm{CH}_{4}+\mathrm{C}_{\mathrm{x}} \mathrm{H}_{\mathrm{y}}+\text { oils \&tars } \\
& \text { Steam-carbon reaction } \mathrm{C} \text { (coal) }+\mathrm{H}_{2} \mathrm{O} \rightarrow \mathrm{CO}+\mathrm{H}_{2} \\
& \text { Reforming-shift reaction } \mathrm{C}_{\mathrm{x}} \mathrm{H}_{\mathrm{y}}+2 \mathrm{x} \mathrm{H}_{2} \mathrm{O} \rightarrow \mathrm{x} \mathrm{CO}_{2}+(2 \mathrm{x}+\mathrm{y} / 2) \mathrm{H}_{2} \\
& \text { Boudouard reaction } \mathrm{C}+\mathrm{CO}_{2} \rightarrow 2 \mathrm{CO}
\end{aligned}
$$

The composition of coal-derived syngas depends on the rank and geographical origin of the coal as well as the process of gasification. Table 1 shows one typical CGS composition.

Table 2.2 Composition of one type of typical coal-derived syngas composition ${ }^{21,22}$

\begin{tabular}{ccccc}
\hline Component & $\mathrm{CO}$ & $\mathrm{H}_{2}$ & $\mathrm{CO}_{2}$ & $\mathrm{H}_{2} \mathrm{O}$ \\
\hline Composition (vol. \%) & 30.0 & 30.6 & 11.8 & 27.6 \\
\hline
\end{tabular}

However, coal syngas commonly contains impurities. Minor and trace components have been classified into three groups: the elements in the first group are condensed phases and can be removed efficiently, such as beryllium (Be), zinc $(\mathrm{Zn})$, chromium $(\mathrm{Cr})$, lead $(\mathrm{Pb})$, potassium $(\mathrm{K})$, sodium $(\mathrm{Na})$, 
vanadium (V), cobalt (Co) and nickel (Ni); those in the second group are between solid and gas phases and cannot be efficiently separated from the gas stream in the cleanup unit, including antimony (Sb), arsenic (As),cadmium (Cd), mercury (Hg), phosphorus (P), chlorine (Cl), sulfur (S), and selenium (Se) ${ }^{23}$; and those in the third group are highly volatile and the least likely to condense ${ }^{24}$. The second group of elements has been identified to be the most detrimental to fuel cell performance. Arsenic, phosphorus, and antimony have all been demonstrated to interact with Ni/YSZ anodes to produce Ni-As, Ni-P, and Ni-Sb secondary phases. Their interaction with the nickel catalyst impacts cell performance and causes severe cell voltage degradation2. Other species can be removed upstream of the anode or pass through the anode with negligible contamination ${ }^{25}$. Among the three detrimental trace elements phosphorus has been studied intensely since it is widely distributed in coals and forms volatile species during gasification. The concentration of phosphorus species in typical coal gas following warm gas cleanup has been estimated at 2 ppm which is detrimental to cell performance ${ }^{26}$. Therefore, it is vital to figure out the mechanism by which phosphorus degrades cell performance.

Table 2.3 Estimates of Trace Contaminant Levels in Coal-Derived Gas ${ }^{27}$

\begin{tabular}{ccc}
\hline Contaminant & $\begin{array}{c}\text { Concentration } \\
\text { (ppm) at the } \\
\text { Kingsport Facility }\end{array}$ & $\begin{array}{c}\text { UND-EERC } \\
\text { Estimate (ppm) }\end{array}$ \\
\hline As $\left(\mathrm{AsH}_{3}\right)$ & 0.15 to 0.58 & 0.2 \\
Thiophene & & 1.6 \\
Chlorine & 2.6 & \\
$\mathrm{CH}_{3} \mathrm{~F}$ & 2.01 & \\
$\mathrm{CH}_{3} \mathrm{Cl}$ & $<1$ & \\
$\mathrm{HCl}$ & 0.05 to 5.6 & \\
$\mathrm{Fe}(\mathrm{CO})_{5}$ & 0.001 to 0.025 & \\
$\mathrm{Ni}(\mathrm{CO})_{5}$ & 2.1 & 0.07 \\
$\mathrm{CH}_{3} \mathrm{SCN}$ & 1.9 & 0.01 \\
$\mathrm{PH} \mathrm{H}_{3}$ & 0.025 & \\
$\mathrm{Antimony}$ & & \\
$\mathrm{Cadmium}$ & & \\
\hline
\end{tabular}




\begin{tabular}{ccc}
\hline Chromium & $<0.025$ & 6.0 \\
Mercury & $<0.025$ & 0.002 \\
Selenium & $<0.15$ & 0.17 \\
Vanadium & $<0.025$ & \\
Lead & & 0.26 \\
Zinc & 9.0 & \\
\hline
\end{tabular}

Discrepancies exist on the reaction products in Ni/YSZ anodes operated in $\mathrm{PH}_{3}$-containing syngas. No in-depth investigation has been performed on the underlying degradation mechanism of Ni/YSZ upon exposure to $\mathrm{PH}_{3}$.

\subsection{Overview of Ni/YSZ SOFC anode interactions with coal-syngas impurities}

Thermodynamic analysis of the trace elements contained in coal-syngas was used to predict the partitioning of trace species between solid and gaseous phases. It was expected that elements such as $\mathrm{Cr}$, $\mathrm{V}, \mathrm{Zn}$, Se, and $\mathrm{Pb}$ form condensed phases and can be easily removed from the syngas system; $\mathrm{Cl}, \mathrm{P}, \mathrm{As}$, and $\mathrm{Hg}$ were observed to form gaseous phases; and S, Cd, and Sb either form condensed or gaseous phases depending on the cleanup operating conditions ${ }^{25}$.

\subsubsection{Interaction with arsenic (As)}

The concentration of $\mathrm{AsH}_{3}$ remains $0.15-0.60 \mathrm{ppm}$ after the coal-syngas goes through the clean-up process $^{28}$. Thermodynamic analysis confirmed that a secondary nickel arsenide phase was formed when $\mathrm{Ni}$ reacted with $\mathrm{AsH}_{3} \mathrm{in}$ this concentration range ${ }^{29,30}$. The proposed degradation mechanism by $\mathrm{AsH}_{3}$ is a loss of electronic percolation due to the formation of nickel arsenide.

Previous studies provided evidence that $\mathrm{As}_{2} \mathrm{O}_{3}$ with a concentration of 1 to $5 \mathrm{ppm}$ in steam will deteriorate the nickel based catalytic activity of the steam reform reaction over time duration of 4 days $^{31}$. The contamination of methanol synthesis catalyst by arsenic was also reported ${ }^{31}$. The mentioned studies limit the operating temperature to 25 to $500{ }^{\circ} \mathrm{C}$. However, normal operating temperatures for a 
SOFC are between 750 to $900^{\circ} \mathrm{C}$. Therefore, the study of arsenic poisoning on SOFC anode degradation should be further conducted at elevated temperatures.

The short-term (100 hours) electrochemical tests by Trembly et al..$^{23}$ at temperature of 750 and $800{ }^{\circ} \mathrm{C}$ showed that degradation due to $\mathrm{AsH}_{3}(1$ and $2 \mathrm{ppm})$ poisoning was not as severe as other impurities, such as $\mathrm{PH}_{3}$ and $\mathrm{H}_{2} \mathrm{~S}$ since the kinetics involved in NiAs formation process were slow. Extended low concentration $(0.1 \mathrm{ppm})$ tests for 800 hours indicated similar results to tests at high $\mathrm{AsH}_{3}$ concentrations.It was concluded that the concentration of $\mathrm{AsH}_{3}$ did not affect the anode performance at short exposure times (below 1000 hours). The poisoning of $\mathrm{AsH}_{3}$ was attributed to the formation of a stable secondary nickel arsenide phase at the outer regions of anode. Long term tests should be conducted to better understand the rate and propagation behavior of secondary nickel arsenide phases in Ni/YSZ anodes.

\subsubsection{Interaction with antimony (Sb)}

Anode degradation upon exposure to antimony occurs rapidly but not significantly. Bao et al. ${ }^{2}$ showed no power degradation in cell performance upon exposure to $8 \mathrm{ppm}$ antimony at $750^{\circ} \mathrm{C}$. At higher temperatures (800 and $850{ }^{\circ} \mathrm{C}$ ) only slight voltage declines were observed at a rate of0.03 $\mathrm{mWcm}^{-2}$ $\mathrm{h}^{-1}$.Their results also indicated that the degradation accelerated at higher current density. It was thermodynamically verified that antimony may react with nickel to form NiSb at a very low conversion ratio. Marina et al. ${ }^{25}$ reported that the formation of an antimony adsorption layer at the interface leads to a decline in electric performance. Moreover, the electronic percolation pathway was blocked after the transformation of nickel to $\mathrm{Ni}_{3} \mathrm{Sb}, \mathrm{Ni}_{5} \mathrm{Sb}_{2}$ and $\mathrm{NiSb}$.

In summary, degradation of cell performance from antimony poisoning is minor in typical coalsyngas with an antimony content of $0.025 \mathrm{ppm}^{27}$.

\subsubsection{Interaction with selenium (Se)}

Marina et al. ${ }^{32}$ measured the variation in cell voltage as a function of operating time after exposure to $\mathrm{H}_{2}$ Se. Their results indicated that cell degradation due to selenium poisoning occurred very quickly and 
reached a steady state after removal of impurities. They also concluded that the degradation caused by $\mathrm{H}_{2}$ Se was slower than that by $\mathrm{H}_{2} \mathrm{~S}^{32}$.

\subsubsection{Interaction with sulfur (S)}

Sulfur, typically in the form of $\mathrm{H}_{2} \mathrm{~S}$ in coal derived syngas, has a large impact on SOFC performance $^{33}$. At low concentrations the adsorption of sulfur on Ni/YSZ is reversible; however at higher concentrations an irreversible sulfidation may take place at reaction sites or at the catalyst surface of the anode. Proposed mechanisms for sulfur based cell degradation are: (1) Physical adsorption/chemisorption of $\mathrm{H}_{2} \mathrm{~S}$ at surface active sites leading to a reduction of surface area for electrochemical reactions; (2) Sulfidation of anode materials resulting in a loss of catalytic activity, conductivity, and stability ${ }^{34}$.

The study of Schubert et al. ${ }^{35}$ found that $\mathrm{H}_{2} \mathrm{~S}$ highly poisoned Ni/YSZ anodes even with low $\mathrm{H}_{2} \mathrm{~S}$ concentration (2 ppm). It was expected that the adsorbed sulfur atoms completely covered the anode even at low concentrations. The $\mathrm{H}_{2} \mathrm{~S}$ adsorption on the anode surface was reversible. The cell could not regenerate full operating conditions by removal of $\mathrm{H}_{2} \mathrm{~S}$ from coal-syngas but the cell could regenerate during the cool down process. XRD analysis indicated that there was no nickel sulfide secondary-phase formation which further demonstrated that the $\mathrm{H}_{2} \mathrm{~S}$ contamination on the Ni/YSZ anode was reversible.

Liu et al. ${ }^{36}$ studied the influence of electric current on sulfur induced cell degradation. They showed that higher current densities led to lower performance losses. It was explained that higher current densities force more oxygen ions to transport from the cathode to the anode, oxidizing $\mathrm{H}_{2} \mathrm{~S}$ to $\mathrm{SO}_{2}$ and removing sulfur from the anode. Based on this mechanism, an alternative solution to reduce $\mathrm{H}_{2} \mathrm{~S}$ poisoning is to cycle the cell power to allow oxygen ions to remove the sulfur impurities.

\subsubsection{Interaction with chlorine $(\mathrm{Cl})$}

The dominant forms of chlorine in coal-syngas are $\mathrm{CH}_{3} \mathrm{Cl}$ and $\mathrm{HCl}$. Studies on SOFC degradation due to chlorine contamination showed electric performance losses in the operating temperature range of 800 to $900{ }^{\circ} \mathrm{C} 2,{ }^{23,37}$. Trembly et al. ${ }^{23}$ reported that when cells were exposed to $\mathrm{HCl}$ vapor (from 20 to160 ppm) performance losses increased with temperature. In addition, higher concentrations of chlorine lead to 
more severe cell degradation. The study of Haga et al. indicated the formation and vaporization of $\mathrm{NiCl}_{2}$ nanoparticles on Ni/YSZ anodes exposed to 100 and $1000 \mathrm{ppm} \mathrm{Cl}_{2}(\mathrm{~g})$ in $\mathrm{H}_{2}$ (g) at $800{ }^{\circ} \mathrm{C}^{37}$.

Bao et al. ${ }^{2}$ studied the influence on temperature on the poisoning effects of chlorine. The tested cells were exposed to $40 \mathrm{ppm} \mathrm{HCl}$ and $\mathrm{CH}_{3}$ Cland tested at various temperatures. For cell-exposures to $\mathrm{HCl}$ at both 750 and $800{ }^{\circ} \mathrm{C}$ no power degradation was seen. When exposed to $\mathrm{CH}_{3} \mathrm{Cl}$, the cell showed severe degradation (degradation rate $\left.0.15 \mathrm{mWcm}^{-2} \mathrm{~h}^{-1}\right)$ at higher temperatures $\left(850{ }^{\circ} \mathrm{C}\right)$. At lower temperatures $\left(800{ }^{\circ} \mathrm{C}\right)$, no noticeable performance loss was observed. However, the conclusion of this study did not agree with the study by Haga et al. ${ }^{37}$. Their thermodynamic calculations demonstrated that nickel chlorine compounds at a reduced atmosphere were not likely to cause a loss of nickel catalytic sites2. They proposed that the absorption of chlorine on surface of nickel catalyst was the source of poisoning. Chlorine may also interact with YSZ network impeding the oxygen ions transportation ${ }^{38}$.

The attack of the electrochemically active sites has been widely accepted as the mechanism of chlorine deterioration of Ni/YSZ anodes, but it remains unclear whether it is a chemical reaction or absorption process. The discrepancies may come from experimental conditions such as temperature, moisture concentration, oxygen partial pressure, and chlorine content.

\subsubsection{Interaction with phosphorus (P)}

Two factors cause cell degradation by $\mathrm{PH}_{3}$ contamination ${ }^{39}$. One factor is the loss of Ni at triple phase boundaries (TPB) caused by material migration3. Material migration is usually caused by concentration gradients, temperature gradients, mechanical stress, and electric fields ${ }^{40}$. Electromigration, migration due to an electric field, has been suggested as the main reason for migration and re-distribution of $\mathrm{Ni}$ element ${ }^{41}$. The other factor is the production of Ni-P secondary phases which result in a decrease of catalytic Ni sites, blockage of gas diffusion channels, and loss of charge transport pathways ${ }^{42}$.

Previous studies on phosphorus poisoning dealt with the production of Ni-P secondary phases with the influence of temperature, phosphorus content, electric current, and moisture concentration. 


\section{Products of nickel phosphorus reaction}

The formation of Ni-P secondary phases deactivates $\mathrm{Ni}$ as a catalyst in hydrogen dissociation, internal reformation of hydrocarbon fuels, and fuel oxidation. The Ni-P secondary phases are less conductive than pure metallic nickel leading to a blockage of electronic transport pathways. In addition, the production of Ni-P compounds induces nickel based particles to migrate and agglomerate at the surface of the Ni/YSZ anode, resulting in a loss of $\mathrm{Ni}$ at electrochemically active reaction sites and insufficient gas transport.

In an attempt to study the kinetics of phosphorus diffusion in the anode layer and quantitatively calculate the reaction rates involved in the phosphorus poisoning process researchers measured the exact forms of Ni-P secondary phases in various cell-operating conditions. The reported results are summarized in Table 2.4.

Table 2.4Summary of previous studies on the forms of Ni-P secondary phases after Ni/YSZ anode exposure to $\mathrm{PH}_{3}$

\begin{tabular}{|c|c|c|c|c|c|}
\hline Authors & Cell structure & $\begin{array}{l}\text { Forms of Ni-P } \\
\text { compounds }\end{array}$ & Characterization method & $\begin{array}{c}\text { Operation } \\
\text { temperatures }\left({ }^{\circ} \mathrm{C}\right)\end{array}$ & Reference \\
\hline \multirow{2}{*}{$\begin{array}{l}\text { Marina et } \\
\text { al. }\end{array}$} & $\begin{array}{l}\text { Electrolyte } \\
\text { supported }\end{array}$ & $\begin{array}{c}\mathrm{Ni}_{3} \mathrm{P}, \mathrm{Ni}_{2} \mathrm{P} \\
\mathrm{Ni}_{5} \mathrm{P}_{2}, \mathrm{Ni}_{12} \mathrm{P}_{5}\end{array}$ & SEM/EDS, SEM/EBSD & $700,750,800$ & \multirow{2}{*}{43,57} \\
\hline & $\begin{array}{c}\text { Anode } \\
\text { supported }\end{array}$ & $\begin{array}{l}\mathrm{Ni}_{3} \mathrm{P}, \mathrm{Ni}_{2} \mathrm{P} \\
\mathrm{PO}_{2}^{-}, \mathrm{PO}_{3}^{-}\end{array}$ & $\begin{array}{l}\text { SEM/(EDS, EBSD,WDS), } \\
\text { TEM, XPS, ToF-SIMS }\end{array}$ & $700,750,800$ & \\
\hline Zhi et al. & $\begin{array}{l}\text { Electrolyte } \\
\text { supported }\end{array}$ & $\mathrm{Ni}_{3}\left(\mathrm{PO}_{4}\right)_{2}$ & XPS, XRD & 900 & 6,47 \\
\hline Xu et al. & $\begin{array}{l}\text { Anode } \\
\text { supported }\end{array}$ & $\begin{array}{l}\mathrm{Ni}_{5} \mathrm{P}_{2}, \mathrm{Ni}_{12} \mathrm{P}_{5} \\
\mathrm{Ni}_{3}\left(\mathrm{PO}_{4}\right)_{2}\end{array}$ & XPS, XRD & $750,800,850$ & 44,63 \\
\hline $\begin{array}{l}\text { Demircan } \\
\text { et al. }\end{array}$ & $\begin{array}{c}\text { Anode } \\
\text { supported }\end{array}$ & $\mathrm{Ni}_{5} \mathrm{P}_{2}, \mathrm{Ni}_{3} \mathrm{P}$ & XRD & 800 & 39,45 \\
\hline $\begin{array}{l}\text { Silva et } \\
\text { al. }\end{array}$ & $\begin{array}{l}\text { Electrolyte } \\
\text { supported }\end{array}$ & $\begin{array}{c}\mathrm{Ni}_{3} \mathrm{P}, \mathrm{Ni}_{12} \mathrm{P}_{5} \\
\mathrm{Ni}_{5} \mathrm{P}_{2} \\
\mathrm{Ni}_{3}\left(\mathrm{PO}_{4}\right)_{2}\end{array}$ & XRD, XPS & 800,900 & 46 \\
\hline
\end{tabular}

In recent years, thermodynamic databases and related software have been used to analyze important issues in material applications. For SOFC muti-component systems temperature and oxygen partial pressure are most significant thermodynamic variables. 
$\mathrm{Xu}$ et al. calculated the Gibbs free energy change of the possible reactions taking place at $800{ }^{\circ} \mathrm{C}$ using the FACTSAGE software.

$$
\begin{gathered}
2 \mathrm{PH}_{3}(\mathrm{~g})+5 \mathrm{Ni}(\mathrm{s}) \rightarrow \mathrm{Ni}_{5} \mathrm{P}_{2}(\mathrm{~s})+3 \mathrm{H}_{2}(\mathrm{~g}) ; \Delta \mathrm{G}(1073.2 \mathrm{~K})=-495.06 \mathrm{~kJ} / \mathrm{mol} \\
2 \mathrm{PH}_{3}(\mathrm{~g})+4 \mathrm{Ni}(\mathrm{s}) \rightarrow 2 \mathrm{Ni}_{2} \mathrm{P}(\mathrm{s})+3 \mathrm{H}_{2}(\mathrm{~g}) ; \Delta \mathrm{G}(1073.2 \mathrm{~K})=-431.53 \mathrm{~kJ} / \mathrm{mol} \\
10 \mathrm{PH}_{3}(\mathrm{~g})+12 \mathrm{Ni}(\mathrm{s}) \rightarrow 2 \mathrm{Ni}_{6} \mathrm{P}_{5}(\mathrm{~s})+15 \mathrm{H}_{2}(\mathrm{~g}) ; \Delta \mathrm{G}(1073 \mathrm{~K})=-1845.84 \mathrm{~kJ} / \mathrm{mol}
\end{gathered}
$$

However, $\mathrm{Ni}_{2} \mathrm{P}$ and $\mathrm{Ni}_{6} \mathrm{P}_{5}$ are not stable at lower temperature. Thus in the process of cooling the cell down there may have been reactions at $873 \mathrm{~K}$ as follows

$$
\begin{gathered}
2 \mathrm{Ni}_{2} \mathrm{P}(\mathrm{s})+\mathrm{Ni}(\mathrm{s}) \rightarrow \mathrm{Ni}_{5} \mathrm{P}_{2}(\mathrm{~s}) ; \Delta \mathrm{G}(873 \mathrm{~K})=-64.73 \mathrm{~kJ} / \mathrm{mol} \\
2 \mathrm{Ni}_{6} \mathrm{P}_{5}(\mathrm{~s})+13 \mathrm{Ni}(\mathrm{s}) \rightarrow 5 \mathrm{Ni}_{5} \mathrm{P}_{2}(\mathrm{~s}) ; \Delta \mathrm{G}(873 \mathrm{~K})=-675.05 \mathrm{~kJ} / \mathrm{mol}^{63}
\end{gathered}
$$

The calculations supported their experimental results that $\mathrm{Ni}_{5} \mathrm{P}_{2}$ was preferably produced when $\mathrm{Ni}$ reacted with $\mathrm{PH}_{3}$.

$\mathrm{Xu}$ et al. also reported the production of nickel phosphate ${ }^{44}$. The proposed mechanism was oxidization of phosphide to phosphate in ambient environment:

$$
\begin{aligned}
& \mathrm{Ni}_{5} \mathrm{P}_{2}(\mathrm{~s})+4 \mathrm{O}_{2}(\mathrm{~g})+2 \mathrm{H}_{2} \mathrm{O}(\mathrm{l}) \rightarrow \mathrm{Ni}_{3}\left(\mathrm{PO}_{4}\right)_{2}(\mathrm{~s})+2 \mathrm{Ni}(\mathrm{OH})_{2}(\mathrm{~s}) ; \Delta \mathrm{G}(300 \mathrm{~K})=-4104.6 \mathrm{~kJ} / \mathrm{mol} \\
& 0.4 \mathrm{Ni}_{12} \mathrm{P}_{5}(\mathrm{~s})+4.9 \mathrm{O}_{2}(\mathrm{~g})+1.8 \mathrm{H}_{2} \mathrm{O}(\mathrm{l}) \rightarrow \mathrm{Ni}_{3}\left(\mathrm{PO}_{4}\right)_{2}(\mathrm{~s})+1.8 \mathrm{Ni}(\mathrm{OH})_{2}(\mathrm{~s}) ; \Delta \mathrm{G}(300 \mathrm{~K})=-2089.48 \mathrm{~kJ} / \mathrm{mol}
\end{aligned}
$$

Kishimoto et al. ${ }^{62}$ systematically constructed the chemical potential diagram of Ni-P-O systems to thermodynamically investigate the chemical stability of the nickel anode against phosphorus containing gaseous species (Figure 2.3). The potential diagram was plotted for the formation of Ni-P compound species as a function of oxygen partial pressure $\left(\log \left\{\mathrm{p}\left(\mathrm{O}_{2}\right) / \mathrm{atm}\right\}\right)$ and phosphorus concentration $(\log \mathrm{a}(\mathrm{P}))$ at a fixed temperature of $800{ }^{\circ} \mathrm{C}^{62}$. The plot indicates that the oxygen partial pressure determines whether the product formed at equilibrium is nickel phosphide or nickel phosphate. The formation of nickel phosphate is preferred at higher oxygen partial pressures $\left(>10^{-17} \mathrm{~atm}\right)$. At lower oxygen partial pressure $\left(<10^{-17} \mathrm{~atm}\right)$ the dominant contaminant products are nickel phosphides. The phosphorus concentration should also be taken into consideration to make a prediction on the exact forms of nickel phosphide present. 


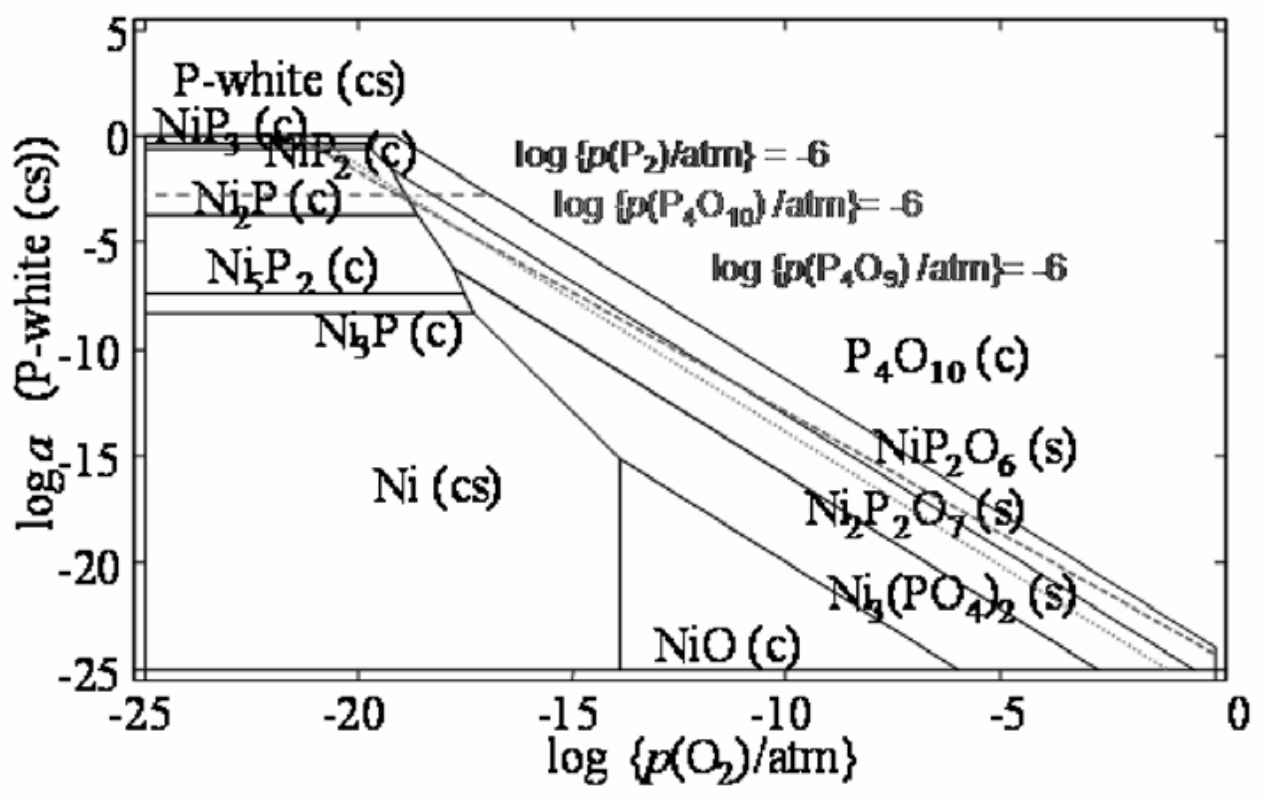

Figure 2.3 Two-dimensional chemical potential diagram for the Ni-P-O system in a log $\left\{p\left(\mathrm{O}_{2}\right) / a t m\right\}$ vs. log a(P) plot at $800{ }^{\circ} \mathrm{C}$. The iso partial pressure lines are displayed for $\mathrm{P}_{2}(\mathrm{~g}), \mathrm{P}_{4} \mathrm{O}_{9}$, and $\mathrm{P}_{4} \mathrm{O}_{10}$ at $10-6$ atm ${ }^{62}$.

In summary, a discrepancy exists on the exact form of the Ni-P secondary phases after the Ni/YSZ anode is exposed to $\mathrm{PH}_{3}$. This discrepancy comes from the various operating conditions used for the fuel cell such as moisture concentration, content of gaseous phosphorous species, partial pressure of oxygen species, and temperature and current conditions.

\section{Influence of phosphine content on phosphorus poisoning}

The $\mathrm{PH}_{3}$ concentration used in previous studies ranges from $0.5 \mathrm{ppm}$ to $20 \mathrm{ppm} 2^{, 43,44,57}$. At lower concentration ranges (below $10 \mathrm{ppm}$ ) increasing $\mathrm{PH}_{3}$ concentration in coal syngas led to higher phosphorus concentration gradients which contribute to the diffusion of phosphorus species to the anode inner layer. Zhi et al. demonstrated that higher $\mathrm{PH}_{3}$ content favored the formation of nickel phosphate both in experiment and thermodynamic analysis ${ }^{47}$. Electrochemical tests indicated that higher phosphine concentrations accelerated the cell degradation ${ }^{57}$. However, the continued increase of $\mathrm{PH}_{3}$ concentration did not cause a notable increase in degradation. This indicates that the Ni/YSZ anode poisoning was triggered at lower $\mathrm{PH}_{3}$ concentrations ${ }^{46}$.

\section{Influence of temperature on phosphorus poisoning}


The temperature range that appeared in literature for $\mathrm{PH}_{3}$ poisoning tests is $700{ }^{\circ} \mathrm{C} 900{ }^{\circ} \mathrm{C}$. Although raising the temperature of the cell can decrease the electrode activation barrier, facilitating kinetic gas diffusion and improving $\mathrm{O}^{2-}$ transport in the electrolyte, it also accelerates the degradation of the Ni/YSZ anodes performance after cell exposure to $\mathrm{PH}_{3}$.

Bao et al. found that at lower temperature $\left(750^{\circ} \mathrm{C}\right)$ and concentrations of a few ppm $(<5 \mathrm{ppm}), \mathrm{PH}_{3}$ poisoning takes place over a hundred hours. However, at higher temperature (above $850{ }^{\circ} \mathrm{C}$ ) weak degradation could happen at the ppm level ${ }^{2}$.

Zhi et al. reported that both charge transfer resistance and mass transfer resistance showed an increase with temperature for anode half cells. Moreover, they estimated the chemical composition change of the anode surface by comparing the XPS peak intensity $I_{P / N i}$ of the P 2p peak to the Ni 2p peak after exposure of the Ni/YSZ half-cell to $\mathrm{PH}_{3}$ in the temperature range of $750{ }^{\circ} \mathrm{C}$ to $900{ }^{\circ}$. They found that higher temperatures lead to higher $I_{P / N i}$ values, indicating the formation of more Ni-P secondary phases. It was proposed that higher temperatures help to overcome the activation barrier for the production of the secondary phase $e^{47}$.

Silva et al. tested Ni-YSZ/Ni-GDC bi-layer anodes at $800{ }^{\circ} \mathrm{C}$ and $900{ }^{\circ} \mathrm{C}$ with $\mathrm{PH}_{3}$ containing syngas. The observed power output dropped significantly for the cell tested at $900{ }^{\circ} \mathrm{C}$. They ascribed the high temperature degradation to the production of more liquid nickel phosphide phases at $900{ }^{\circ} \mathrm{C}$. It was also proposed that the severe thermal mismatch between the anode and electrolyte at higher temperatures resulted in structural instability ${ }^{46}$.

\section{Influence of electric current on phosphorus poisoning}

The study of Zhi et al. demonstrated that the application of an electric current accelerates the degradation of $\mathrm{PH}_{3}$ poisoning ${ }^{6}$. Microstructure characterization showed that the anode surface was damaged more severely when the cell was operated with a current load. Further chemical analysis indicated an agglomerated Ni-P compound layer at the surface of the Ni/YSZ anode. The destruction of the porous structure of $\mathrm{Ni} / \mathrm{YSZ}$ anode induced the electrochemical degradation. In addition, nickel 
diffusion to the surface under current was proposed to lead to cell degradation ${ }^{6}$. Silva et al. claimed that with current load $\mathrm{H}_{2} \mathrm{O}$ and $\mathrm{CO}_{2}$ diffused out from the TPB sites interfering with the $\mathrm{Ni}-\mathrm{PH}_{3}$ reaction.Ni migration was also observed with current and it was attributed to the transfer of electron momentum ${ }^{46}$.

\section{Influence of moisture concentration on phosphorus poisoning}

The investigation of Guo et al. concluded that $\mathrm{PH}_{3}$ poisoning accelerated anode degradation when the cell was operated in steam containing syngas. In addition, by applying different moisture concentrations (3 vol\% and 6 vol\%) with 10 ppm $\mathrm{PH}_{3}$ they found that higher moisture content resulted in more severe cell degradation ${ }^{48}$. In contrast, the work of Silva et al. showed no obvious dependence of cell degradation on moisture levels (8 vol\%, 16 vol\%, 27.1 vol\% in 20 ppm $\mathrm{PH}_{3}$ containing syngas) ${ }^{46}$.

In summary, the phosphorus poisoning of Ni/YSZ anodes has been widely investigated. However, the degradation mechanism is still poorly understood. The process of Ni re-distribution is still unclear for material migration. Discrepancy in the exact form of anode poisoning by phosphorus and for the Ni-P contamination still exists.

\subsubsection{Summary}

Table 2.5 summarizes the studies on SOFC performance degradation upon exposure to various impurities in coal derived syngas. The listed studies only include the variables of impurity content (ppm level), duration time, and operation temperature $\left(750{ }^{\circ} \mathrm{C} \sim 850^{\circ} \mathrm{C}\right)$. However, the experimental conditions differ in the applied fuel cell types (anode supported or electrolyte supported), electric current load, moisture concentration compositions of fuel gases, and oxygen partial pressure in the testing chamber. All of these factors greatly affect the cell performance degradation.

Table 2.5 SOFC performance degradation upon exposure to impurities of coal derived syngas

\begin{tabular}{|c|c|c|c|c|c|}
\hline \multirow{2}{*}{ Contaminant } & \multirow{2}{*}{$\begin{array}{l}\text { Exposure Level } \\
\text { (ppm) }\end{array}$} & \multicolumn{3}{|c|}{ Degradation (\%) with exposure duration } & \multirow{2}{*}{ Reference } \\
\hline & & $750^{\circ} \mathrm{C}$ & $800^{\circ} \mathrm{C}$ & $850^{\circ} \mathrm{C}$ & \\
\hline
\end{tabular}




\begin{tabular}{|c|c|c|c|c|c|}
\hline As $\left(\mathrm{As}_{2}(\mathrm{~g})\right.$ & 10 & 10 (70 h) & Cell failure & & 2 \\
\hline \multirow{2}{*}{$\left.\mathrm{AsH}_{3}(\mathrm{~g})\right)$} & 1 & $<5(800 \mathrm{~h})$ & & & 23 \\
\hline & 1 & & $<6(600 \mathrm{~h})$ & & 49 \\
\hline $\mathrm{Cd}(\mathrm{g})$ & 5 & & $<1(120 \mathrm{~h})$ & $>20(120 \mathrm{~h})$ & 2 \\
\hline $\mathrm{CH}_{3} \mathrm{Cl}(\mathrm{g})$ & 40 & & $<1(150 \mathrm{~h})$ & $5(60 \mathrm{~h})$ & 2 \\
\hline \multirow{3}{*}{$\mathrm{HCl}(\mathrm{g})$} & 40 & $<1(120 \mathrm{~h})$ & $<1(110 \mathrm{~h})$ & & 2 \\
\hline & 100 & & $1.6(300 \mathrm{~h})$ & $1.5(100 \mathrm{~h})$ & 25 \\
\hline & 1000 & & $0.94(100 \mathrm{~h})$ & & 50 \\
\hline $\mathrm{Cl}_{2}(\mathrm{~g})$ & 5 & & negligible & & 51 \\
\hline \multirow{3}{*}{ Hg(g) } & 0.18 & $<1$ & $<1$ & $<1$ & 27 \\
\hline & 1 & & 0.4 & & 52 \\
\hline & 7 & $<1(150 \mathrm{~h})$ & $1.4(130 \mathrm{~h})$ & & 2 \\
\hline \multirow{4}{*}{$\begin{array}{c}\mathrm{P}\left(\mathrm{PH}_{3}(\mathrm{~g}) \text { or }\right. \\
\left.\mathrm{HPO}_{2}(\mathrm{~g})\right)\end{array}$} & 2 & & $18(100$ h) & & 2,50 \\
\hline & 10 & & $54(135$ h) & & 25 \\
\hline & 35 & $7(120$ h) & $7.5(80 \mathrm{~h})$ & & 2 \\
\hline & 10 & $11(200 \mathrm{~h})$ & $8.6(113 \mathrm{~h})$ & $21(211 \mathrm{~h})$ & 27,44 \\
\hline \multirow{2}{*}{$\mathrm{H}_{2} \mathrm{Se}(\mathrm{g})$} & 0.5 & & 5 (200 h) & & 53 \\
\hline & 5 & & $25(75 \mathrm{~h})$ & & 53 \\
\hline $\mathrm{Sb}(\mathrm{SbO}(\mathrm{g}))$ & 8 & $<1(100 \mathrm{~h})$ & $2(160 \mathrm{~h})$ & $2(120$ h) & 2 \\
\hline $\mathrm{Zn}(\mathrm{g})$ & 9 & $<1(150 \mathrm{~h})$ & & 1.5 (120 h) & 2 \\
\hline $\mathrm{NH}_{3}(\mathrm{~g})$ & 5000 & & & negligible & 54 \\
\hline $\mathrm{Si}+\mathrm{Na}$ & $\begin{array}{l}\text { Si } 20000 \text {, } \\
\text { Na } 1000\end{array}$ & & & $200(600 \mathrm{~h})$ & 41 \\
\hline \multirow{2}{*}{$\mathrm{H}_{2} \mathrm{~S}(\mathrm{~g})$} & 2 & & $12.7(<1 \mathrm{~h})$ & & 36 \\
\hline & 50 & & 20.6 (120 h) & & 36 \\
\hline
\end{tabular}




\section{Chapter 3: Degradation Behavior and Mechanism of the Ni/YSZ Cermet SOFC Anode upon $\mathrm{PH}_{3}$ Contamination}

\subsection{Introduction}

The direct utilization of coal-derived syngas (CSG) as a fuel for Solid Oxide Fuel Cells (SOFCs) is capable of increasing energy efficiency, reducing operating costs, and co-producing other commercially useful commodities such as hydrogen. However, the commonly used coal syngas contains impurities such as arsenic, antimony, chlorine, cadmium, selenium and phosphorus, which may interact with anode catalyst and impact cell performance or cause severe cell voltage degradation ${ }^{2}$.Among all the impurities phosphorus (P), in the form of phosphine in the coal syngas, has been singled-out with particular scrutiny because it is most detrimental to cell performance ${ }^{26}$. Therefore, it is vital to unveil the underlying mechanism of phosphorus poisoning which directly affects the cell performance.

The cell degradation caused by $\mathrm{PH}_{3}$ contamination can be mainly ascribed to two factors ${ }^{39}$. The first is the loss of nickel (Ni) at triple phase boundary (TPB) caused by material migration ${ }^{47}$. The material migration is usually attributed to concentration gradients, temperature gradients, mechanical stress and the electric force ${ }^{55}$. Among them, electromigration has been suggested as the reason for migration and redistribution of Ni element ${ }^{56}$. Second is the production of Ni-P chemical compounds which results in a decrease of catalytic Ni sites, blockage of gas diffusion channels and a loss of charge transport pathways6. However, the mechanism of cell degradation and the process of Ni re-distribution are still unclear. As well, there are discrepancies in the exact forms of products when the anode is poisoned by phosphorus.

In this study, an attempt is made to understand the electrochemical behavior of the anode upon exposure toPH $\mathrm{P}_{3}$ and the mechanism of Ni redistribution by testing anode half cells with and without 
current load. In addition, experimental tests were conducted on anode half cells fueled with both coalsyngas and dry coal-syngas (without water containing) to clarify the influence of moisture concentration, especially for the formation of Ni-P secondary phases.

\subsection{Experimental}

\subsubsection{Cell setup}

The half-cell configuration was constructed as shown in Figure 3.1. A Ni-YSZ/YSZ/Pt structured anode half cell was constructed in which a $150 \mu \mathrm{m}$ dense YSZ disk was used as the electrolyte, a $60 \mu \mathrm{m}$ thick porous NiO-YSZ (50-50) was used as the working electrode (WKD), a $60 \mu$ m platinum layer was painted as the counter electrode (CTR). A Pt strip electrode was painted at the edge of the electrolyte as the reference electrode (REF). Ni mesh strips were pasted on the surface of the electrodes. Silver wires were utilized as electrical leads.

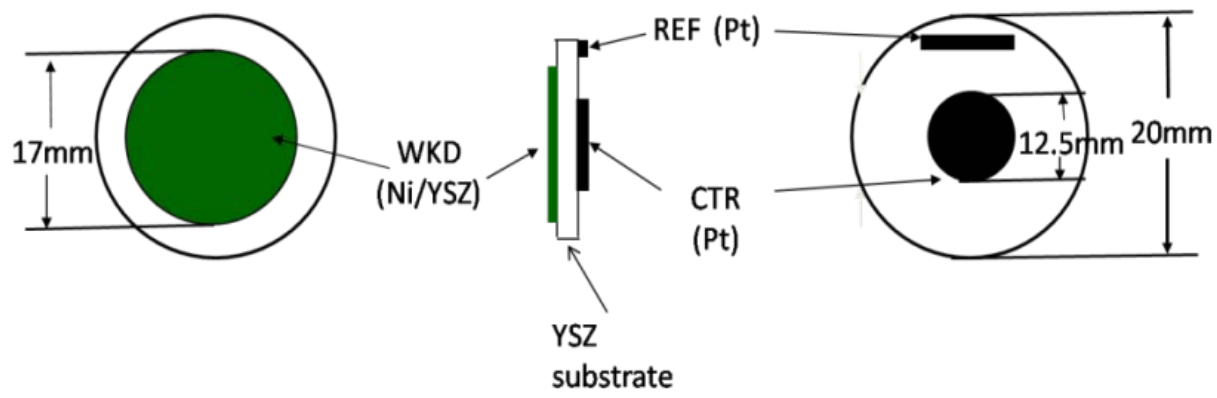

Figure 3.1 Configuration for the structure of the anode half cell

\subsubsection{Electrochemical test}

The electrolyte-supported half-cell was placed at the center of a quartz tube inside a tube furnace. The electrode was heated to $800{ }^{\circ} \mathrm{C}$ at $1{ }^{\circ} \mathrm{C} \mathrm{min}^{-1}$ using $\mathrm{N}_{2}$ as a protecting gas. $\mathrm{H}_{2}$ was introduced to reduce $\mathrm{NiO}$ to $\mathrm{Ni}$ after the cell temperate reached $800^{\circ} \mathrm{C}$. The cells were exposed to $5 \mathrm{ppm}$ phosphine containing coalsyngas for different time ( 0.5 hour, 1 hour, 2 hours, 4 hours, 6 hours, 8 hours and 24 hours), operated with current loading $\left(0.25 \mathrm{~A} / \mathrm{cm}^{2}\right)$ and without current loading. Coal-syngas $\left(30 \% \mathrm{CO}, 30.6 \% \mathrm{H}_{2}, 11.8 \% \mathrm{CO}_{2}\right.$, and $27.6 \% \mathrm{H}_{2} \mathrm{O}$ by volume) and dry coal-syngas (41.4\% CO, $42.3 \% \mathrm{H}_{2}$, and $16.3 \% \mathrm{CO}_{2}$ by volume) were 
applied as the fuel gases, separately (Scheme 3.1). A Solartron SI 1260 impedance/grain-phase analyzer was utilized to measure the impedance spectra.

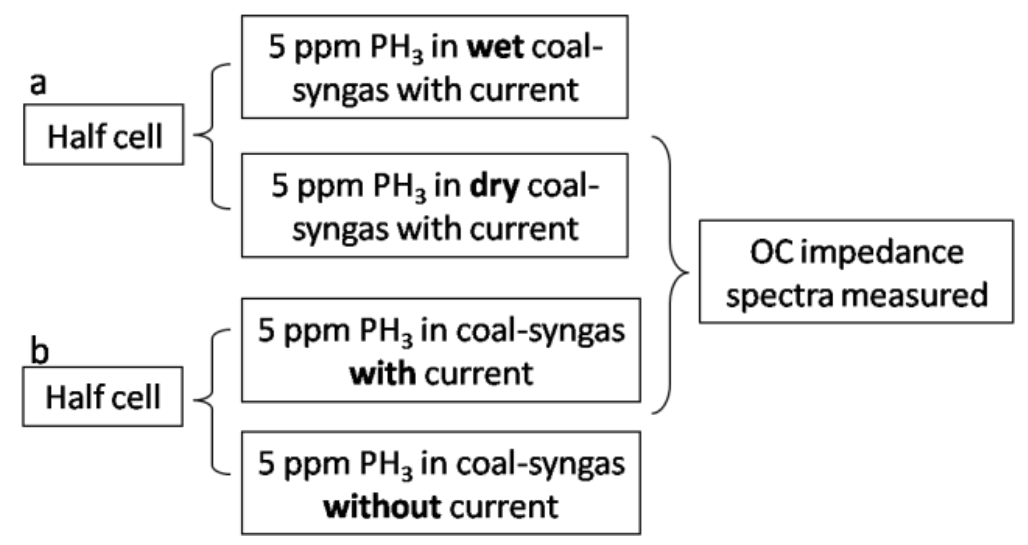

Scheme 3.1 Procedures for anode half-cell test: (a) in dry and moisture containing coal syngas, (b) with and without current load.

\subsubsection{SEM/EDS characterization}

Following the termination of electrochemical tests, the surface and cross-section of individual cells were characterized with a JEOL-7600F scanning electron microscopy (SEM) and an energy dispersive xray spectroscope (EDS) system. The surface observation by SEM provides information on the open porosity of anodes after operated at various conditions. The morphology and elemental distribution on half-cell cross-section were analyzed by SEM and EDS. Elemental maps were drawn by EDS to study the influences of electric current and phosphine diffusion on nickel redistribution.

\subsubsection{XPS characterization}

In order to clarify the forms of Ni-P secondary phases after anode exposure to $5 \mathrm{ppm}^{\mathrm{PH}_{3}}$ at different conditions, X-ray photoelectron spectroscopy (XPS) analysis was carried out on the anode surface of post-test half-cells using a PHI 5000 VersaProbe system with monochromatic Al Ka radiation(1486.6 eV).

XPS detection was carried out on the sub-surface underneath of the carbon deposition after the anode surface was cleaned by ion sputtering to remove carbon by the moisture free syngas. 


\subsubsection{SIMS characterization}

In an attempt to help examine the exact chemical forms of Ni-P secondary phases and chemical distributions with higher sensitivity after the half-cell was exposed to $\mathrm{PH}_{3}$, time-of-flight secondary ion mass spectrometry (ToF-SIMS; PHI TRIFT III (Physical Electronics, Inc., Eden Prairie, MN)) analysis was employed on the cross-section of specimens to examine the exact chemical forms of Ni-P secondary phases and chemical distributions after the half-cell exposed to $\mathrm{PH}_{3}$.

Time-of-Flight Secondary Ion Mass Spectrometry (ToF-SIMS) is a surface-sensitive analytical method that uses a pulsed ion beam (Cs or micro-focused Ga) to remove molecules from the very outermost surface of the sample. The surface atoms and molecules of a solid sample are bombarded with pulsed primary ion beam. The excited atoms and molecules are emitted from the atomic mono-layers on the surface and extracted. The extracted particles are usually called secondary ions. The secondary ions are then accelerated and ejected into a flight channel. The flight time of particles reaching the detector is measured to determine the mass of particles. As shown in Figure 3.2, the velocity of particles after acceleration can be expressed as a function of particle mass (here the acceleration energy is fixed).

$$
\text { velocity }=\sqrt{\frac{2 \text { energy }}{\text { mass }}}
$$

Then by taking into consideration of the path length of the particles, we can build up a relationship between the flight time and the mass of particles.

$$
\text { Flighttime }=\text { pathlength } \times \sqrt{\frac{\text { mass }}{2 \text { energy }}}
$$

The components typically included in a ToF-SIMS instrument are an ultrahigh vacuum system, a pulsed ion beam gun (Ga or Cs), a flight path with either circular or linear in design and a mass detector system. In the context elemental and chemical analysis, ToF-SIMS is a beneficial complementary to other spectroscopy technologies, such as Ion Scattering Spectroscopy (ISS), X-ray Photoelectron Spectroscopy (XPS or ESCA), Scanning Electron Microscopy (SEM) and Auger Electron Spectroscopy (AES). The main strengths over other related techniques can be summarized as follows: 


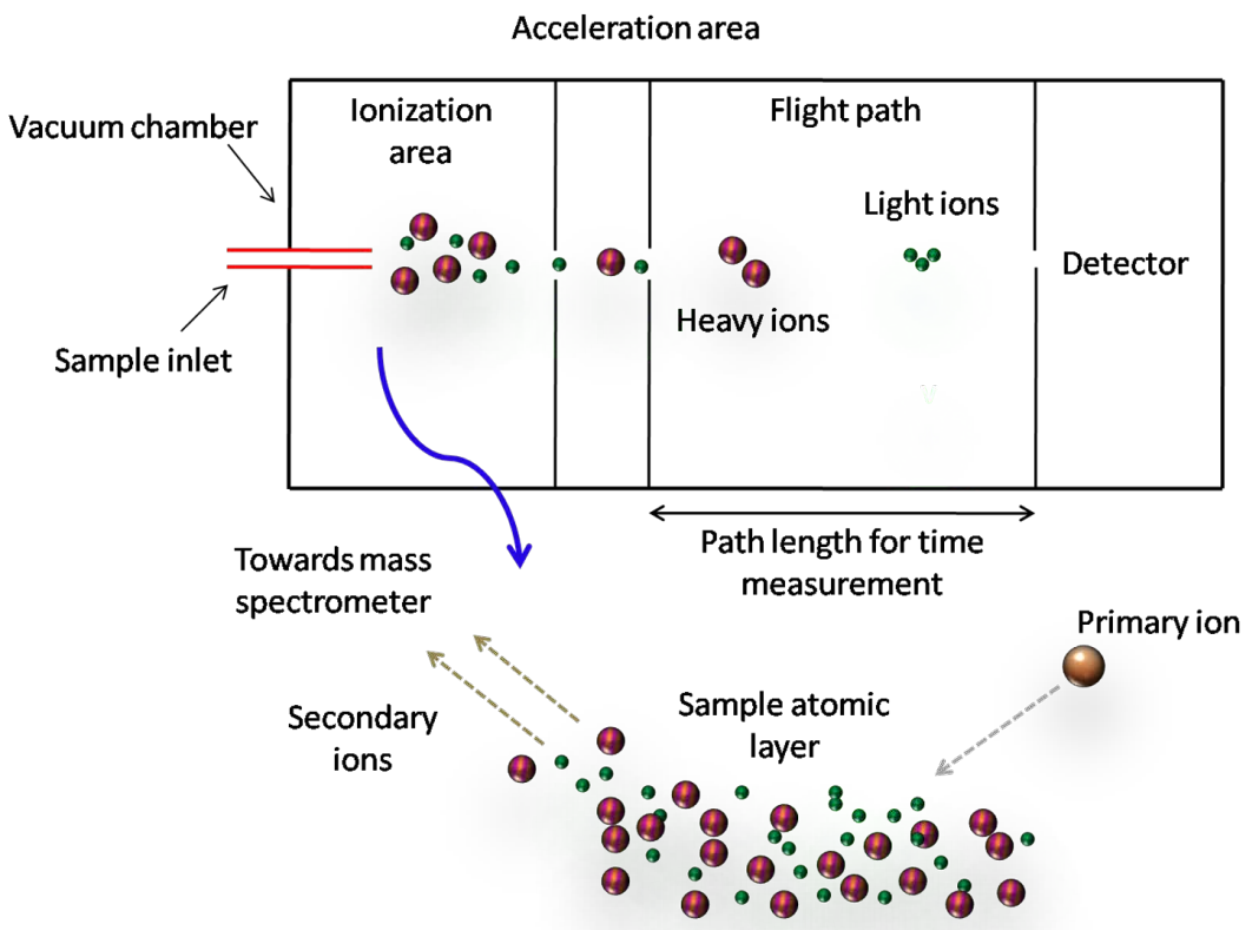

Figure 3.2 Schematic illustration of the principle of time of fight-second ion mass spectroscopy (ToF-SIMS)

(a) Surveys of all masses on material surfaces. These may include single ions (positive or negative), individual isotopes, and molecular compounds, as well as elements which can be detected with poor sensitivity, such as hydrogen, lithium, beryllium and baron.

(b) Elemental and chemical mapping on a sub-micron scale contains a great deal of molecular/structural information for both organic and inorganic surfaces.

(c) Elemental sensitivity is also greater and can be an order of ppm of a monolayer. While other techniques such as XPS, AES and XRF have sensitivities of only 0.2 atomic percent.

(d) Analysis on surfaces of both insulating and conducting samples.

(e) Non-destructive analysis.

(f) High sensitivity for trace elements or compounds (ppm to ppb for most species)

(g) Depth profiling (in the near surface environment, on the order of individual atomic layers to 10s of nanometers); 
(h) Elemental analysis with higher resolution. SIMS can easily distinguish zirconium and phosphorus, which have a close binding energy and cannot be separated by EDS.

The pulsed primary ion beam applied in our detection was $\mathrm{Ga}^{+}$. The images of positive ions $\left(\mathrm{Ni}^{+}, \mathrm{Zr}^{+}\right.$, $\left.\mathrm{Y}^{+}, \mathrm{ZrO}^{+}, \mathrm{Ni}_{2} \mathrm{P}^{+}, \mathrm{Ni}_{3} \mathrm{P}^{+}, \mathrm{Ni}_{5} \mathrm{P}_{2}^{+}, \mathrm{Ni}_{12} \mathrm{P}_{5}^{+}\right)$and negative ions $\left(\mathrm{O}^{-}, \mathrm{PO}^{-}, \mathrm{PO}_{2}^{-}, \mathrm{PO}_{3}^{-}\right)$were collected in an area of $200 * 200 \mu \mathrm{m}$.

\subsection{Results}

\subsubsection{Electrochemical Performance}

At $800{ }^{\circ} \mathrm{C}$, impedance spectra were taken after the electrolyte-supported anodes were exposed to 5 ppm $\mathrm{PH}_{3}$ containing coal-syngas for 0.5 hour, 1 hour, 2 hours, 4 hours, 6 hours, 8 hours and 24 hours. The tested half-cells showed quick degradation after $\mathrm{PH}_{3}$ was introduced. Figure 3.3a indicates results for a half-cell operated at current density of $0.25 \mathrm{~A} / \mathrm{cm}^{2}$ and the current remains constant during half-cell exposure to 5 ppm $\mathrm{PH}_{3}$. In Figure 3.3b, a half cell was operated without current load. In Figure 3a \& b, the high-frequency intercept, corresponding to the ohmic resistance $\mathrm{R}_{\mathrm{ohm}}$, shows no obvious change $\left(\mathrm{R}_{\mathrm{ohm}}\right.$ fluctuates at $0.1 \Omega \mathrm{cm}^{2}$ ) while the polarization resistance $\mathrm{R}_{\mathrm{p}}$ makes a significant contribution to the total resistance increase.
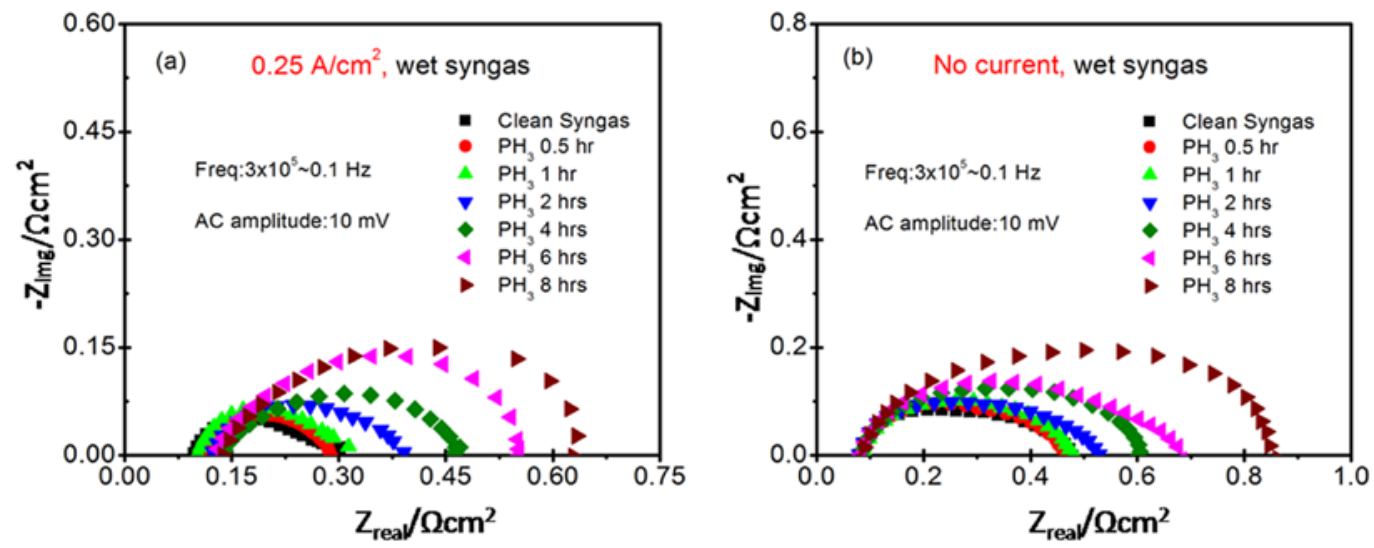

Figure 3.3 Nyquist plots of the impedance spectra taken from the half cells operated in 5 ppm $\mathrm{PH}_{3}$ contained coalsyngas at $800^{\circ} \mathrm{C}$ : (a) at current density of $0.25 \mathrm{~A} / \mathrm{cm}^{2}$ in wet coal-syngas, (b) without current load in wet coal-syngas. 
The increase in polarization resistance $\mathrm{R}_{\mathrm{p}}$ of the cell after exposure to $\mathrm{PH}_{3}$ is compared to that of cell after exposure to clean syngas. The rate of polarization resistance increase is calculated as follows:

$$
\mathrm{H}(\%)=\frac{\left(\mathrm{R}_{\mathrm{P}_{1}}-\mathrm{R}_{\mathrm{PQ}}\right)}{\mathrm{R}_{\mathrm{Po}}} \times 100 \%
$$

where, $R_{p 0}$ represents the polarization resistance of cell after exposure to clean syngas, while $R_{p 1}$ represents the polarization resistance of cell after exposure to $5 \mathrm{ppm} \mathrm{PH}_{3}$ at given time. $\mathrm{R}_{\mathrm{p}}$ is derived from

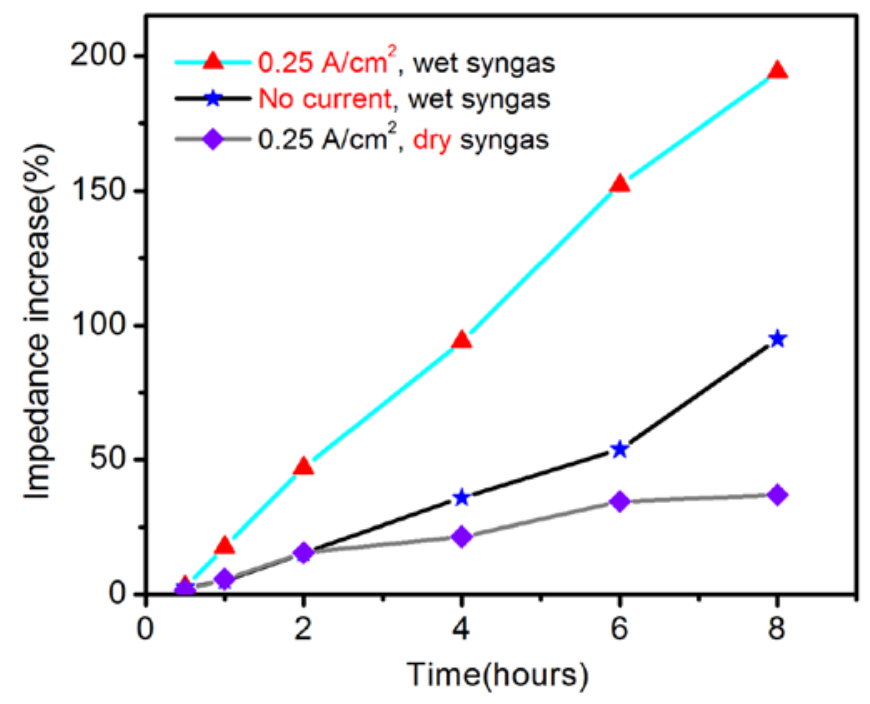

Figure 3.4 Polarization impedance increases as a function of operation time ( $5 \mathrm{ppm} \mathrm{PH}_{3}$ at $\left.800^{\circ} \mathrm{C}\right)$ : at current density of $0.25 \mathrm{~A} / \mathrm{cm}^{2}$, without current load, and in dry coal-syngas, respectively.

the difference of interactions at the real axis. The polarization resistance increase is illustrated as a function of the operation time at different operation conditions in Figure 3.4. After 5 ppm $\mathrm{PH}_{3}$ was added to coal-syngas, polarization resistance increased as time of exposure extended. The rate of polarization impedance increase of the cell operated at $0.25 \mathrm{~A} / \mathrm{cm}^{2}(24.3 \%$ / hr in average) is observed to be over twice bigger than that of the cell operated without current load $(11.9 \% / \mathrm{hr}$ in average). The increase of the polarization impedances (24.3\% / hr in average) in moisture-containing syngas is much faster (about 4 times) than (4.6\% / hr in average) that in moisture-free syngas. It should be noted that the increase of the 
polarization resistance of the cell operated in $\mathrm{PH}_{3}$ containing dry coal-syngas (Figure 3.4) is not very obvious.

\subsubsection{SEM/EDX Analysis}

SEM was applied to observe the anode surface morphology. Figure 3.4 shows the surface appearance of the anodes operated in various conditions: (Figure 3.5a) clean syngas; (Figure 3.5b) 5 ppm $\mathrm{PH}_{3}$ containing syngas for 24 hours at current density of $0.25 \mathrm{~A} / \mathrm{cm}^{2}$ in moisture condition; (Figure 3.5c) 5 ppm $\mathrm{PH}_{3}$ containing syngas for 24 hours without current load in moisture condition; (Figure 3.5d) 5 ppm $\mathrm{PH}_{3}$ containing syngas for 24 hours at current density of $0.25 \mathrm{~A} / \mathrm{cm}^{2}$ without moisture. It shows a well defined surface appearance with uniformly distributed particles and large amount of pores after the anode exposure to clean coal-syngas. In contrast, the half-cells exposed to $\mathrm{PH}_{3}$ showed particle agglomeration and nonuniform distribution on the anode surface. The agglomeration for the anode operated with current load was more severe than that without current load. In addition, the samples operated without moisture showed less surface damage. 

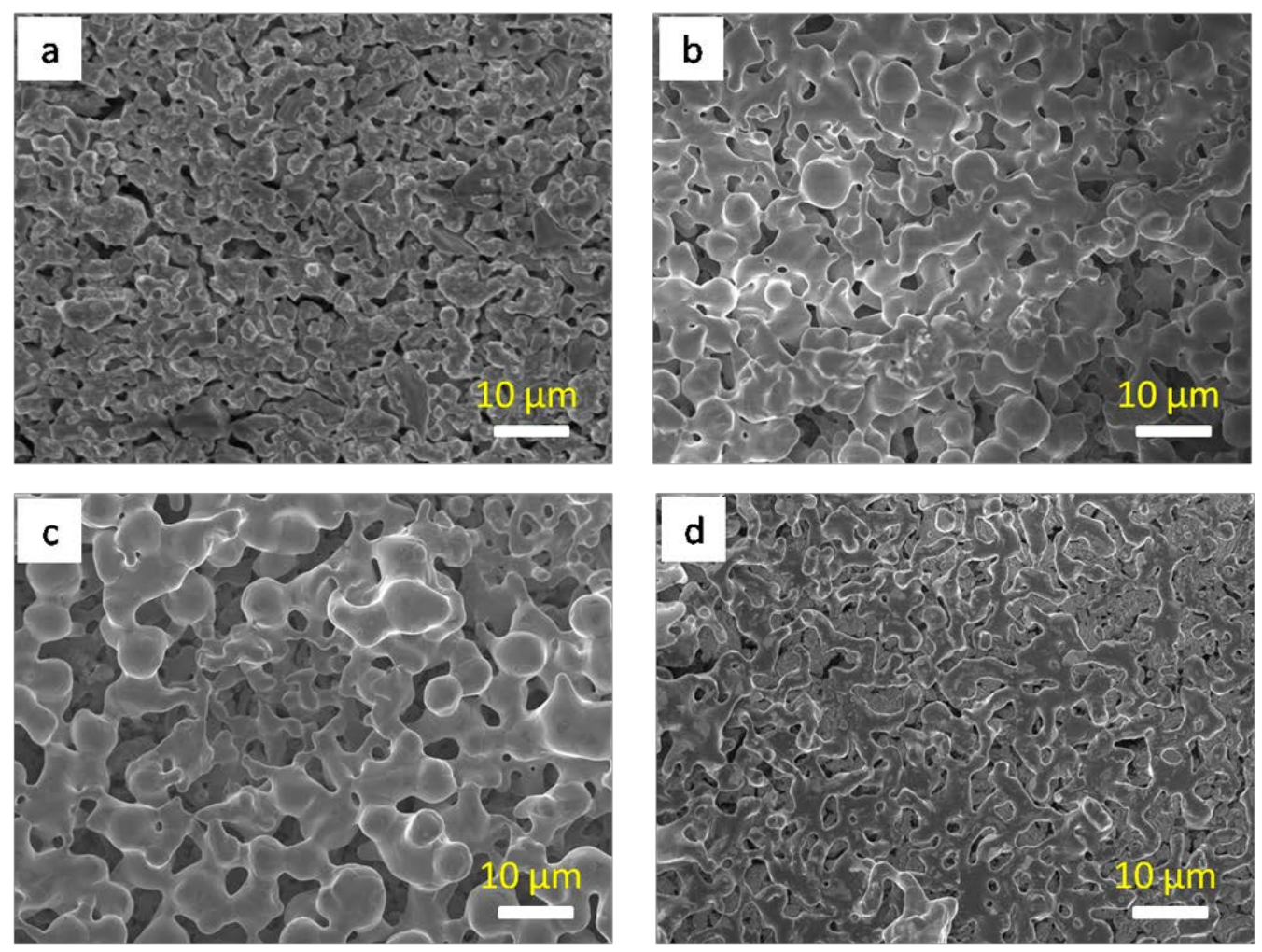

Figure 3.5 SEM images of the Ni-YSZ anode surface after cell exposure to $\mathrm{PH}_{3}$-containing syngas at $800{ }^{\circ} \mathrm{C}$ for:(a) 0 hour (clean cell) (b) 24 hours at current density of $0.25 \mathrm{~A} / \mathrm{cm}^{2}$ (c) 24 hours without current load (d) 24 hours with dry syngas.

In order to further support our result that electric current facilitates the anode surface damage upon $\mathrm{PH}_{3}$ exposure, SEM observation was carried out on the surfaces of the samples after exposure to $\mathrm{PH}_{3}$ for different time both with current and without current load. Figure 3.6 shows the surface morphology of anode half-cells exposed to $\mathrm{PH}_{3}$ for 1 hour (3.6a \& 3.6b) and 4 hours (3.6c \& 3.6d). With electric current load, the surface particles showed more severe agglomeration and fewer pores were seen on the open surface. In addition, the surface damage increased as the time of exposure to $\mathrm{PH}_{3}$ extended. 

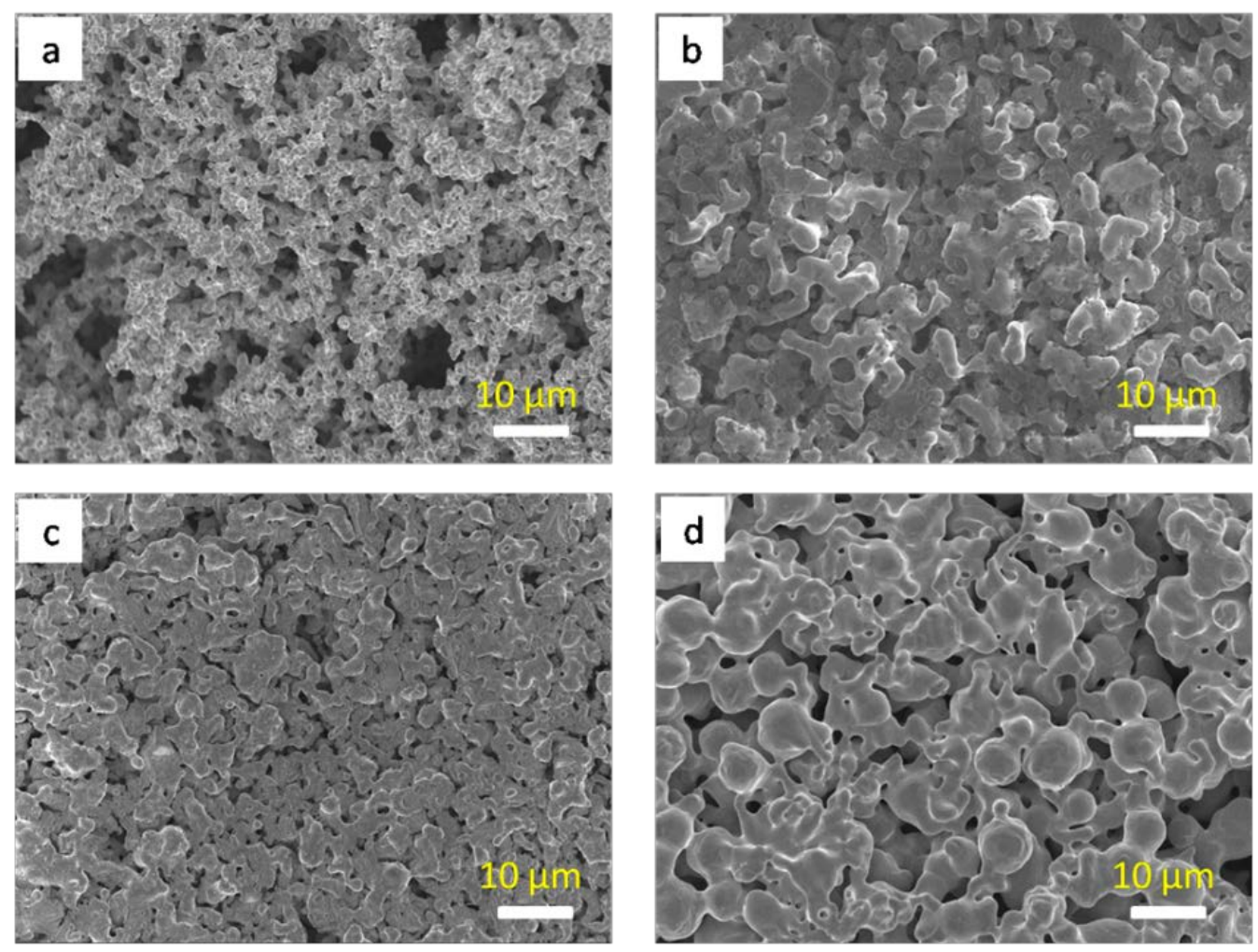

Figure 3.6 SEM images of the Ni-YSZ anode surface after cell exposure to $\mathrm{PH}_{3}$-containing syngas $800{ }^{\circ} \mathrm{C}$ for 1 hour:

(a) no current load (b) at the current density of $0.25 \mathrm{~A} / \mathrm{cm}^{2}$; and 4 hours: (c) no current load (d) at the current density of $0.25 \mathrm{~A} / \mathrm{cm}^{2}$.

In an attempt to quasi-quantitatively analyze the open porosity of Ni-YSZ anodes after $\mathrm{PH}_{3}$ poisoning, surface appearances of clean and poisoned anodes were examined with a SEM (JEOL-7600F). 20 SEM photographs were collected in different surface regions of each sample. As show in Figure 3.7, the collected images were regenerated into digital images by adjusting their contrast and brightness. Then the processed digital images were analyzed with home-made program (Appendix A) using MATLAB software to quasi-quantify the open porosity. The data process was shown in Figure 3.8: we first clustered several separate regions from the image in Figure 3.8b based on gradient value, then we get image in Figure 3.8c and the total number of classes after clustering is 2. In Figure 3.8c, two different strong contract colors were used to fill and represent our regions. The open porosity was obtained by comparing the area ratio of the pore-represented class region to the whole area. 

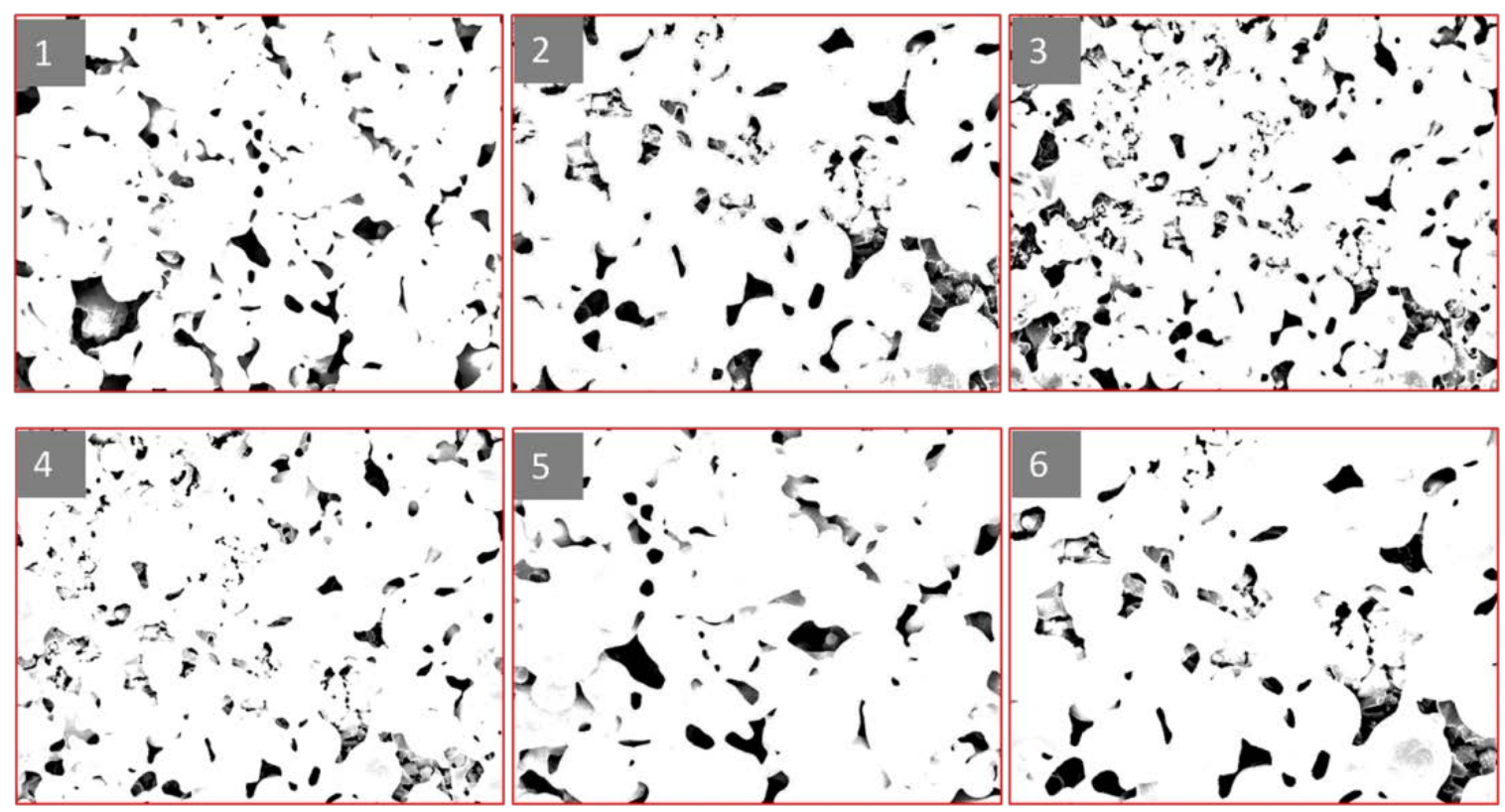

Figure 3.7 Digital images after adjusting the contrast and brightness of the original SEM images collected from the surface of anode half-cell after exposure to $5 \mathrm{ppm} \mathrm{PH}_{3}$ for 24 hours at current density of $0.25 \mathrm{~A} / \mathrm{cm}^{2}$.

The surface open porosities of individually tested samples were statically calculated by averaging the porosity values from over 20 different surface regions. The standard deviation was below 3\% for the data process. The porosity values of samples operated under $\mathrm{PH}_{3}$ contamination for different time and at various current conditions are summarized in Figure 3.8d. The results indicate that the surface porosity of $\mathrm{Ni} / Y S Z$ anode decreases obviously after exposure to $\mathrm{PH}_{3}$. In addition, applying current promotes a great reduction of surface open porosity. The quasi-quantitative analysis of anode open porosity well explains that the surface particles agglomerate and may block the fuel gas diffusion path ways. 


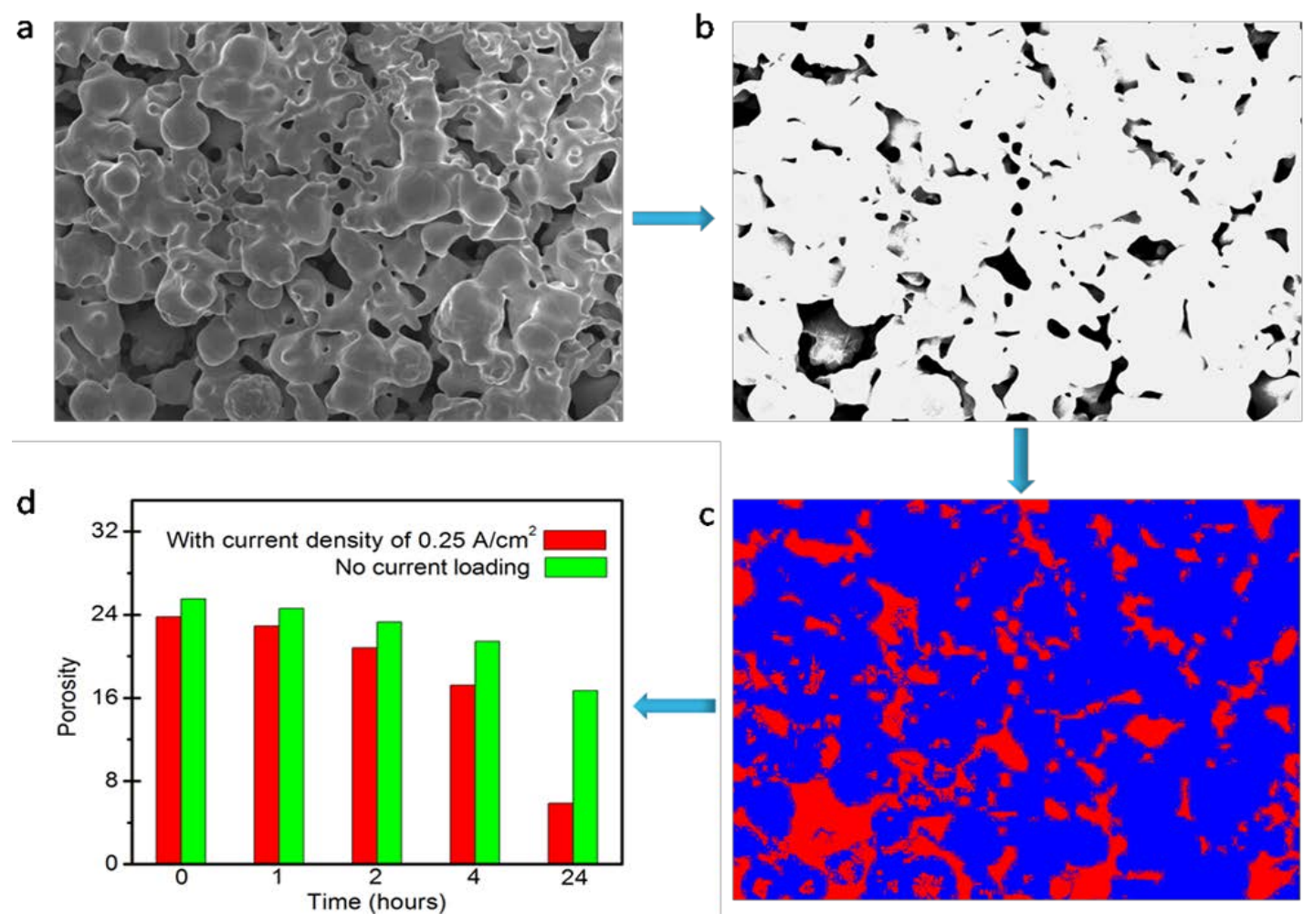

Figure 3.8 (a) (b) \& (c) from one surface image of anode half cell after exposure to 5 ppm $\mathrm{PH}_{3}$ for 24 hours at current density of $0.25 \mathrm{~A} / \mathrm{cm}^{2}$ (a) original SEM image (b) after adjusting the image contrast and brightness(c) recolored by using computer program (appendix A); (d) surface porosity as a function of operation time after cell exposure to $5 \mathrm{ppm} \mathrm{PH}_{3}$ at $800^{\circ} \mathrm{C}$.

In order to quantitatively study the Ni re-distribution in the tested anode, EDS was operated on the cross-section of the half-cells after $\mathrm{PH}_{3}$ contamination in various conditions. The distributions of Ni, $\mathrm{Zr}, \mathrm{P}$ elements were presented in EDS mapping. Figure 3.9 and Figure 3.10 show the elemental distribution mapping with cross-section appearance of the anodes operated at current density of $0.25 \mathrm{~A} / \mathrm{cm}^{2}$ and without current load at 5 ppm phosphorus for 24 hours, respectively. The relatively less Zr distribution at the top layer of anode could be ascribed to the formation and agglomeration of Ni-P secondary phase at anode surface ${ }^{57}$. 

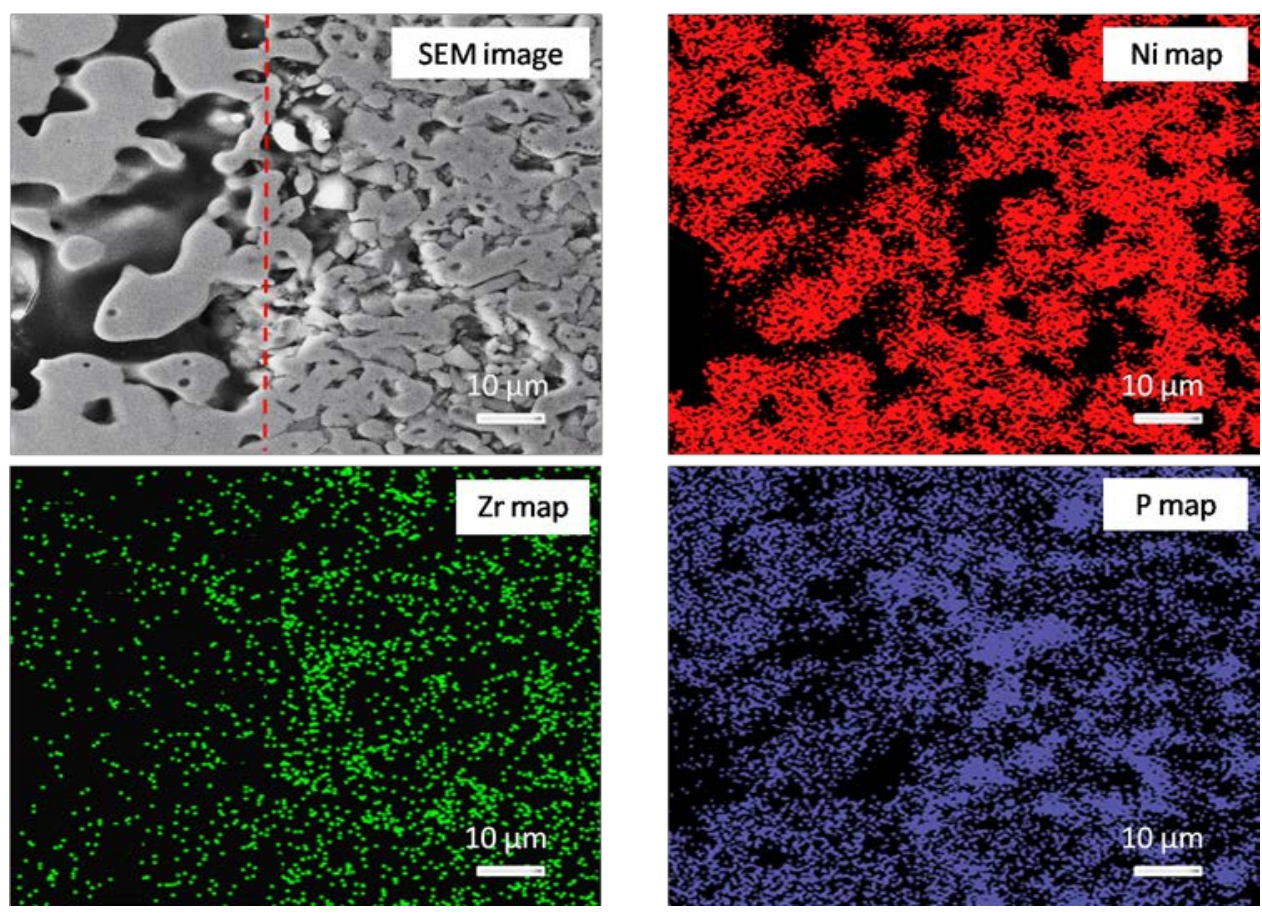

Figure 3.9 Elemental maps collected during cross-sectional SEM analysis. Ni converted to Ni-P secondary phases in anode of electrolyte-supported cells by $5 \mathrm{ppm} \mathrm{PH}_{3}$ containing coal-syngas at $800^{\circ} \mathrm{C}$ for 24 hours at current density of $0.25 \mathrm{~A} / \mathrm{cm}^{2}$. The top surface of the anode is shown at the left boundary in each image.
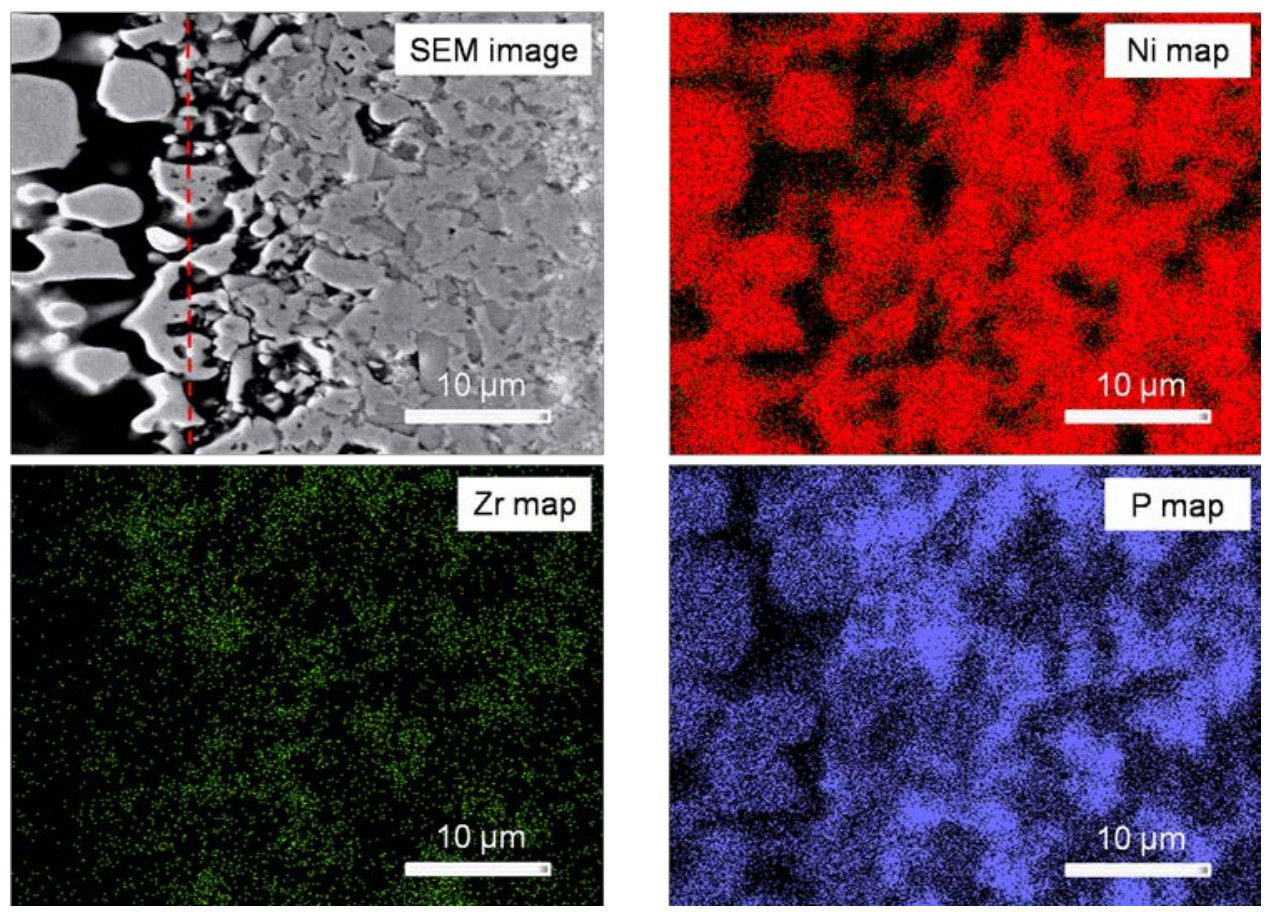
Figure 3.10 Elemental maps collected during cross-sectional SEM analysis. Ni converted to Ni-P secondary phases in anode of electrolyte-supported cells by 5 ppm $\mathrm{PH}_{3}$ containing coal-syngas at $800{ }^{\circ} \mathrm{C}$ for 24 hours without current load. The top surface of the anode is shown at the left boundary in each image.

Twenty images collected from different areas of each half-cell were measured. The extent of Ni migration was estimated by the ratio (D) of the thickness of Ni-P compound layer to the thickness (m) of whole Ni/YSZ anode layer.

$$
\mathrm{D}(\%)=\frac{m}{n} \times 100 \%
$$

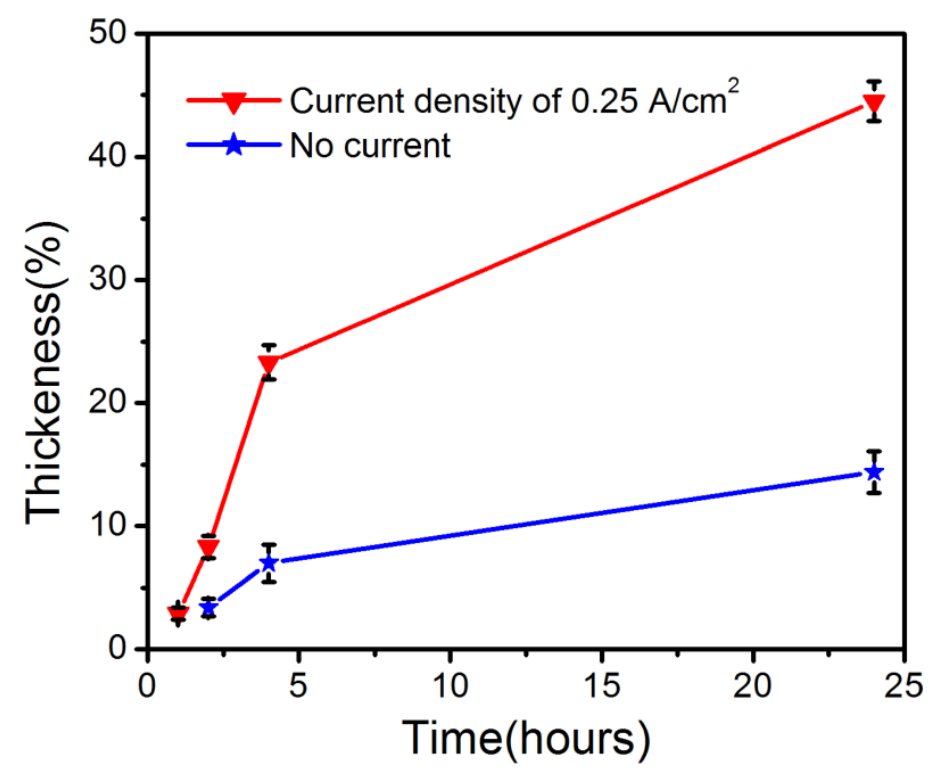

Figure 3.11 Thickness of the top Ni-P compound layer compared to that of the whole anode layer as a function of time of anode half-cell upon exposure to $5 \mathrm{ppm} \mathrm{PH}_{3}$ containing coal-syngas at $800^{\circ} \mathrm{C}$.

The Ni-P compound layer thicknesses on the surface of anode after $\mathrm{PH}_{3}$ exposure with time at different current conditions were measured and summarized in Figure 3.11. The Ni-P-phase layer thickness is observed to increase with the time of anode exposed to $\mathrm{PH}_{3}$. The layer thickness of the anode operated at current density of $0.25 \mathrm{~A} / \mathrm{cm}^{2}$ shows faster increase than that without current load. It illustrates that electric current facilitates the Ni-P layer formation at anode surface. 


\subsubsection{XPS Characterization}

In order to identify the phosphorus contamination product in Ni/YSZ composite anodes upon exposure to $\mathrm{PH}_{3}$, XPS analysis was performed on the anodes surface before and after being exposed toPH $\mathrm{P}_{3}$. It should be noted that the anode surface after being exposed to dry coal-syngas was deposited with a thick carbon layer, thus the spectrum was obtained after removing of carbon deposition by ion gun sputtering. Figure 3.12a reveals the XPS spectra of P 2p core level. For half-cell operated in moisturecontaining syngas, the XPS spectra indicate the existence of oxidized phosphorus. The binding energy of $\mathrm{P} 2 \mathrm{p}_{3 / 2}$ for the cell after being operated both with current and without current load is comparable with that of $\mathrm{Ni}_{3}\left(\mathrm{PO}_{4}\right)_{2}{ }^{58}$, which has a value of $133.3 \mathrm{eV}$. While for half-cell operated in moisture-free $\mathrm{PH}_{3}$ containing coal-syngas, the anode surface was deposited with a carbon layer. After removal of carbon deposition by ion sputtering, no phosphorus was found by XPS. Figure 3.12b is the XPS spectra of Ni 2p core level. Both oxidized $\mathrm{Ni}$ and metallic Ni were found to exist in the sample before and after exposure to $\mathrm{PH}_{3}$. The peak at $852.5 \mathrm{eV}$ was attributed to metallic nickel ${ }^{59}$, while the peak at $855.6 \mathrm{eV}$ could be assigned to the oxidized $\mathrm{Ni}^{60}$. Figure 3.12c shows the XPS spectra of $\mathrm{Zr} 3 \mathrm{~d}$ core level. No $\mathrm{Zr}$ signal was detected on the surface of the samples upon exposure to $5 \mathrm{ppm} \mathrm{PH}_{3}$, indicating a surface Ni-rich layer covering the Ni/YSZ composite.
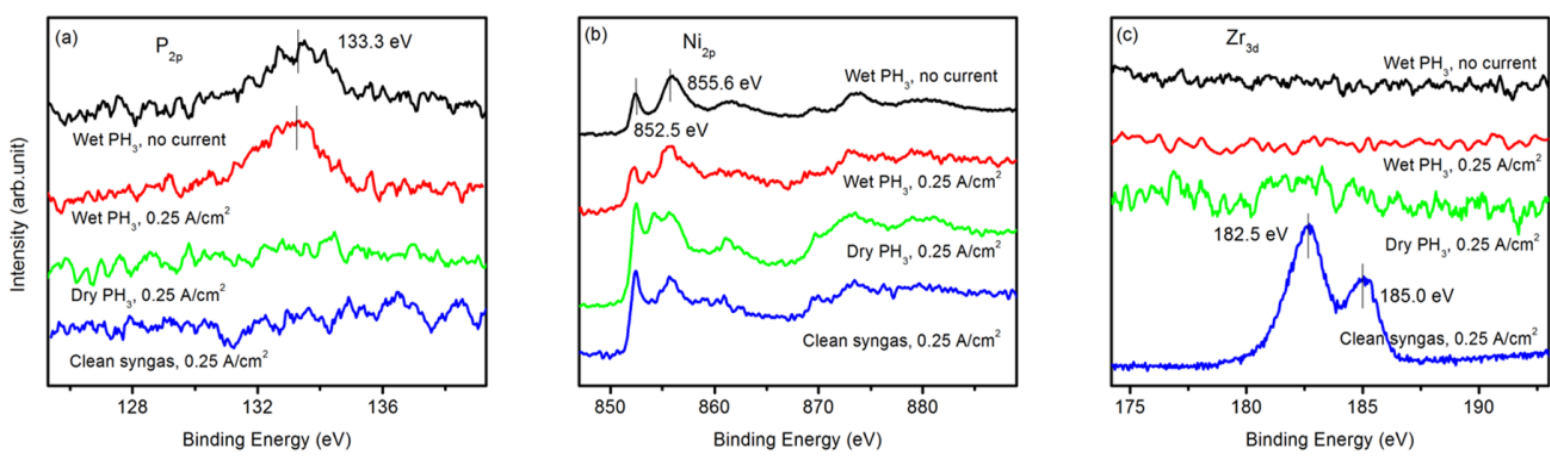

Figure 3.12 XPS spectra of (a) P 2p core level, (b) Ni 2pcore level (c) Zr 3d core level obtained from the surface of $\mathrm{Ni} /$ YSZ anodes after operation in various conditions. 


\subsubsection{SIMS Analysis}

To further examine the chemical structure of the Ni-P secondary phases in Ni/YSZ composite anodes after $\mathrm{PH}_{3}$ poisoning and to study the nickel diffusion behavior, ToF-SIMS analysis was conducted on the cross-section of Ni/YSZ anodes as shown in Figure 3.13 and Figure 3.14. In Figure 3.13, the images present the distribution of ions and ion clusters of anode after exposure to phosphine with moisture (Figure 3.13a) and without moisture (Figure 3.13b). In Figure 3.13a, the distributions of Ni and $\mathrm{Zr}$ reveal the fact that an agglomerated Ni layer covers at the top of Ni/YSZ. In Figure 3.13b, no noticeable phosphorus signal was detected, indicating tiny or no phosphorus diffused in the bulk layer of Ni/YSZ anode. This is consistent with the result of XPS analysis on Ni/YSZ anode surface. The results of SIMS line analysis of the samples operated in different current conditions were plotted in Figure 3.14. Figure 3.14a represents a depth profile of the cell mentioned in Figure 3.13a, in which a higher concentration of $\mathrm{Ni}$ is observed at the top surface of Ni/YSZ anode, while little $\mathrm{Zr}$ is observed in this layer. The phosphorus formats in the whole anode are $\mathrm{PO}^{-}, \mathrm{PO}_{2}^{-}, \mathrm{PO}_{3}^{-}$and they have the same distribution. It is consistent with the XPS analysis. Figure 3.14b is the depth profile of the cell operated in $\mathrm{PH}_{3}$ containing syngas without current load. Only $\mathrm{PO}^{-}, \mathrm{PO}_{2}^{-}, \mathrm{PO}_{3}^{-}$ion clusters are observed. It is noted that $\mathrm{PO}^{-}, \mathrm{PO}_{2}^{-}$and $\mathrm{PO}_{3}{ }^{-}$clusters only appear at top layer. To compare, the XPS analysis involved at the anode surface indicate the existence of oxidized phosphorus. In addition, our SIMS line profile for the anode exposed to phosphine in moisture free condition shows much less phosphorus along the whole cross-section of $\mathrm{Ni}$ /YSZ anode. 

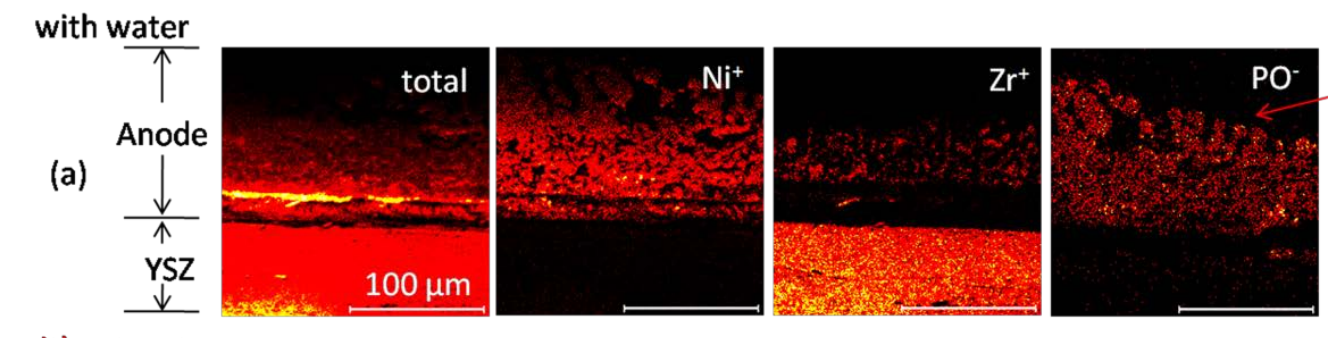

Anode

Surface

without water
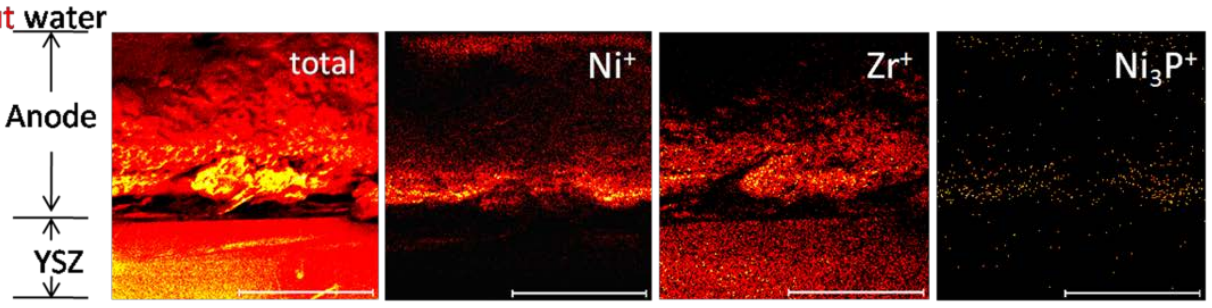

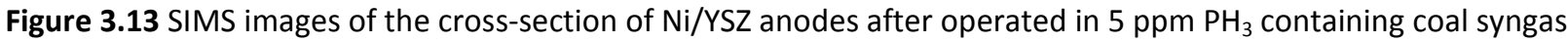
for 24 hours at current density of $0.25 \mathrm{~A} / \mathrm{cm}^{2}$ : (a) with moisture, (b) without moisture.
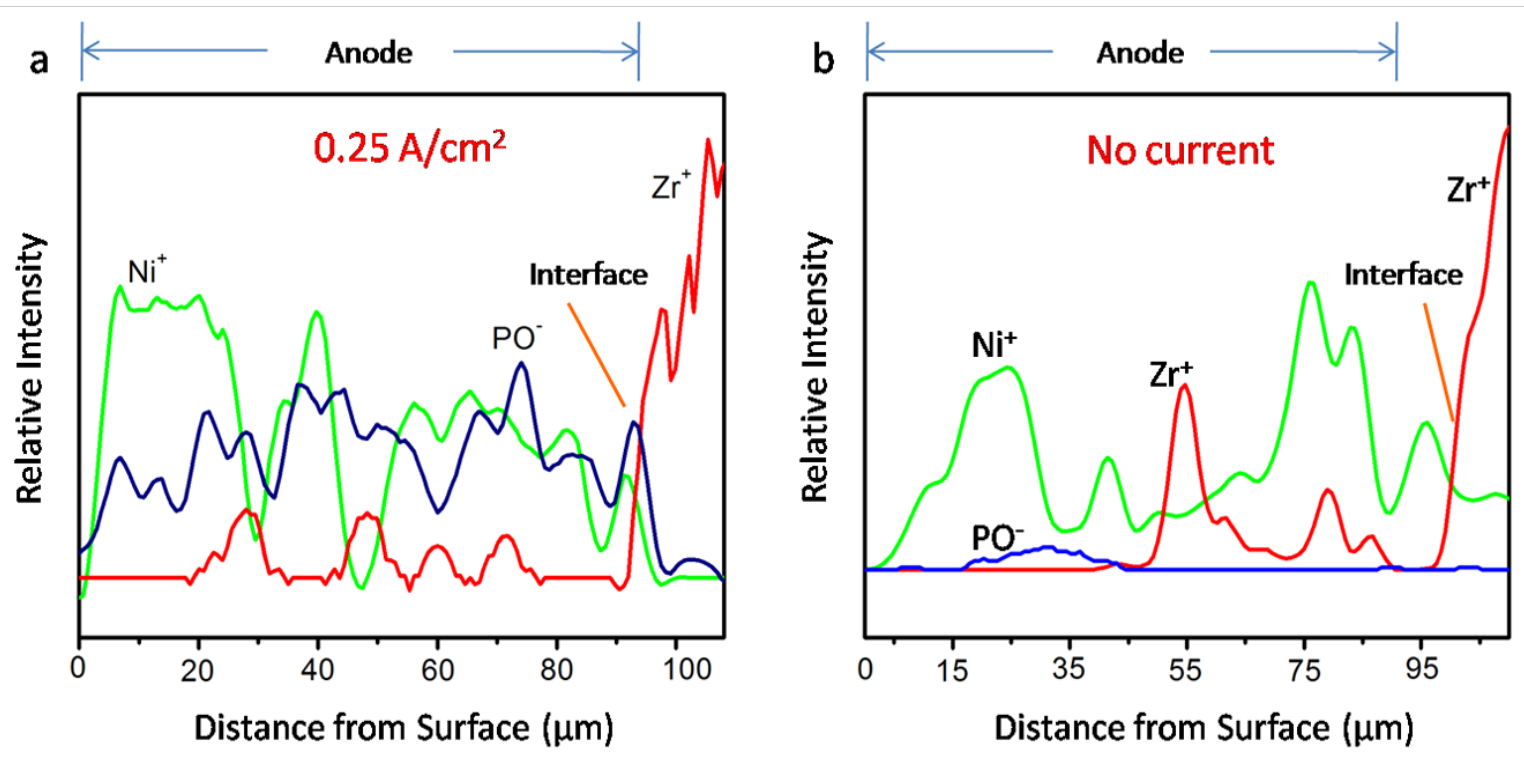

Figure 3.14 SIMS line analysis of the cross-section of $\mathrm{Ni} / \mathrm{YSZ}$ anodes after operated in $5 \mathrm{ppm} \mathrm{PH}_{3}$ containing syngas for 24 hours: (a) at current density of $0.25 \mathrm{~A} / \mathrm{cm}^{2}$, (b) without current load.

\subsection{Discussion}




\subsubsection{Influence of electric current}

The reaction between nickel and phosphorus can reduce the length of triple phase boundary (TPB) in $\mathrm{Ni} / Y S Z$ anode resulting in an immediate drop in cell performance. The SEM characterization coincided with the impedance behavior, showing more severe degradation when anode was operated at current density of $0.25 \mathrm{~A} / \mathrm{cm}^{2}$.

The XPS and SIMS analysis indicated the contamination product was nickel phosphate when the electrode was operated in moisture at current density of $0.25 \mathrm{~A} / \mathrm{cm}^{2}$. Moreover, previous XRD detection also showed the existence of $\mathrm{Ni}_{3}\left(\mathrm{PO}_{4}\right)_{2}{ }^{42}$. The coexistence of $\mathrm{Ni}$ and $\mathrm{Ni}_{3}\left(\mathrm{PO}_{4}\right)_{2}$ is a result of consumption of gaseous phosphorus containing species to form $\mathrm{Ni}_{3}\left(\mathrm{PO}_{4}\right)_{2}$. Applying electric current facilitates the formation of a larger amount of oxygen ions. The diffused phosphine concentration at a depth of $30 \mu \mathrm{m}$ below the anode surface is around $0.1 \mathrm{ppm}^{61}$ after half-cell is exposed to $5 \mathrm{ppm} \mathrm{PH}_{3}$ for 20 hours. Based on the diffused phosphine concentration, the deduced critical value of oxygen partial pressure for the formation of $\mathrm{Ni}_{3}\left(\mathrm{PO}_{4}\right)_{2}$ is about $10^{-17}$ atm from the results of chemical potential diagram ${ }^{62}$. Namely, when the oxygen partial pressure is below $10^{-17} \mathrm{~atm}$, the dominant products of phosphorus contamination are nickel phosphides; while when the oxygen partial pressure is above $10^{-17}$ atm, the products are demonstrated to be $\mathrm{Ni}$ phosphates. At the current density of $0.25 \mathrm{~A} / \mathrm{cm}^{2}$, it will theoretically produces $7.80 \times 10^{-5} \mathrm{~mol} /\left(\mathrm{cm}^{2} \cdot \mathrm{min}\right)$ oxygen ions $\left(\mathrm{O}^{2-}\right)$. The difference in appearance between the open circuit (OC) and anodic polarization can be interpreted in terms of the oxygen potential difference in the two cases. Applying current load yields a larger amount of oxygen ions, that is, under the OC condition, the oxygen potential is rather low so that the nickel phosphide are first formed, whereas the nickel phosphate can be directly formed as a reaction among the metallic nickel, emitted water vapor and the phosphorus containing species ${ }^{62}$. However, the results differ from the formation of nickel phosphides reported in literature ${ }^{63}$ with the same moisture conditions. The difference may come from the various thickness of anode involved in experiments. In our electrolyte supported half-cell, the anode layer thickness is around $60 \mu \mathrm{m}$; while in the anode supported half cells as reported in previous literature ${ }^{39,63}$, the anode thickness

is much larger (hundreds of microns) ${ }^{45,63}$. Thus for electrolyte supported half-cell, the electrons motivated 
$\mathrm{O}^{2-}$ arrives at the anode top layer and oxidizes the phosphorus species. However, for a thick anode, the motivated $\mathrm{O}^{2-}$ may have been consumed by $\mathrm{H}_{2}$ and $\mathrm{CO}$ in the coal-syngas in the long diffusion path. The previous thermodynamic calculation demonstrated that at higher oxygen partial pressure, the production of nickel phosphate is preferred ${ }^{62}$. Consequently for the electrolyte supported anode half-cell, the products of $\mathrm{Ni}$ and phosphorus reaction at current density of $0.25 \mathrm{~A} / \mathrm{cm}^{2}$ are nickel phosphates, as the stable form of $\mathrm{Ni}_{3}\left(\mathrm{PO}_{4}\right)_{2}$. Without current load, nickel phosphate was found at the Ni/YSZ anode surface, which was ascribed to the oxidization of anode by the relatively larger oxygen partial pressure from moisture in coalsyngas or the post exposure of samples in air.

The presence of Ni-P secondary-phase layer covering at the surface of Ni/YSZ layer indicates $\mathrm{Ni}$ migrating from the bulk material to the anode surface. Material migration is usually ascribed to several factors, such as chemical potential difference caused by concentration gradients ${ }^{64}$, thermal migration introduced by temperature gradients ${ }^{65}$, diffusion driven by stress gradients ${ }^{66}$, and electromigration ${ }^{67}$. Since the local temperature variation has been demonstrated to be too small $\left(\approx 1{ }^{\circ} \mathrm{C}\right)$ to evidently motivate atoms to move ${ }^{68}$, the oriented Ni migration to the anode surface is not likely caused by thermal migration. The thermal expansion mismatching resulted stress between $\mathrm{Ni}$ and YSZ can be released due to the presence of quasi-liquid phase (for instance, $\mathrm{Ni}_{3} \mathrm{P}$ has a melting point of $870{ }^{\circ} \mathrm{C}$ close to the anode operation temperature $800{ }^{\circ} \mathrm{C}$ ) which wets the interface well ${ }^{69}$. In addition, the stress introduced by the conversion of $\mathrm{Ni}$ to Ni-P phases is not strong enough to drive the cracks to propagate ${ }^{70}$. Thereby the stress induced atom migration is theoretically negligible. Electromigration is thus believed to result in the oriented Ni migration, which was verified by the experimental results that the thickness of the surface Nirich layer increased when cell was operated at current density of $0.25 \mathrm{~A} / \mathrm{cm}^{2}$. Moreover, it was also experimentally established that even no current load, the surface Ni-rich layer thickened gradually with the time of cell operated in $\mathrm{PH}_{3}$ elongated, which had been ascribed to the conversion of $\mathrm{Ni}$ to Ni-P compounds ${ }^{57}$. This indicates that the chemical potential difference of phosphorus between the surface and the bulk of anode may also serve as a driven force for the Ni migration. Surface reconstruction of particles consisting of more than a single component has the tendency of lowering the surface free energy: 
atoms or molecules which lower the surface free energy tend to accumulate at the surface. Surface segregation of $\mathrm{Ni}$ atoms to the YSZ particles can be ascribed to the lower melting point of Ni atoms and Ni-P compounds which have the lower surface energy and therefore accumulate at the surface. The melting points of $\mathrm{Ni}, \mathrm{YSZ}, \mathrm{Ni}_{3} \mathrm{P}$, and $\mathrm{Ni}_{3}\left(\mathrm{PO}_{4}\right)_{2}$ are given in table 3.1. The decrease in melting points from Ni to Ni-P compounds indicates the tendency of surface energy reduction after chemical reaction of nickel with phosphorus.

Table 3.1 Melting points of chemical formula involved in anode contamination process

\begin{tabular}{ccccc}
\hline Formula & $\mathrm{Ni}^{71}$ & $\mathrm{YSZ}^{72}$ & $\mathrm{Ni}_{3} \mathrm{P}^{73}$ & $\mathrm{Ni}_{3}\left(\mathrm{PO}_{4}\right)_{2}{ }^{7475}$ \\
\hline Melting point $\left({ }^{\circ} \mathrm{C}\right)$ & 1453 & 2700 & 870 & 1345 \\
\hline
\end{tabular}

FactSage databases have been involved to predict the contamination products after Ni/YSZ anode was exposed to $\mathrm{PH}_{3}$. The thermodynamic tendency of phosphorus to form $\mathrm{Ni}_{3} \mathrm{P}^{26}, \mathrm{Ni}_{5} \mathrm{P}_{2}{ }^{63}, \mathrm{Ni}_{12} \mathrm{P}_{5}^{63}, \mathrm{Ni}_{2} \mathrm{P}^{26}$ and $\mathrm{Ni}_{3}\left(\mathrm{PO}_{4}\right)_{2}{ }^{76}$ has been demonstrated. For pure chemical reactions, Gibbs free energy change shows nickel phosphides are the most stable forms of Ni-P secondary phases at equilibrium. However, the electric current has largely affected the reactions by promoting more $\mathrm{O}^{2-}$ to anode.

\subsubsection{Influence of moisture concentration}

The rate of polarization impedance increase is greater for the anode exposed to $\mathrm{PH}_{3}$ with moisture than that without moisture. It indicates that Ni-cermet-based SOFCs anode is more susceptible to degradation due to $\mathrm{PH}_{3}$ in the presence of moisture than under dry conditions. The water presence increases the oxygen partial pressure and catalyzes the degradation of anode when $\mathrm{PH}_{3}$ is added to the coal-syngas. For the wet coal-syngas fed cells, it is assumed that the sources of water are the water contained in coal-syngas, the water primarily absorbed on the surface of Ni and YSZ, and the water produced during the operation of the half-cell.

While for the cells fed with dry coal-syngas, the electrochemical test shows less performance degradation. Moreover, XPS and SIMS analysis indicate no presence of phosphorus in the bulk of anode 
materials. Considering absence of moisture led to carbon deposition on the anode surface before addition of $\mathrm{PH}_{3}$ to coal-syngas, further diffusion of $\mathrm{PH}_{3}$ to $\mathrm{Ni} / \mathrm{YSZ}$ bulk was blocked. But small molecules, like $\mathrm{H}_{2}$ could still diffuse into the anode inner layer, feeding the cell operation. It can be demonstrated from the impedance results that there is no concentration polarization in Nyquist plots. Therefore, anode showed more severe degradation with moisture upon exposure to $\mathrm{PH}_{3}$ containing coal-syngas.

\subsection{Summary}

The results of our investigation on the influence of electric current and moisture concentration on $\mathrm{PH}_{3}$ poisoning behavior of Ni/YSZ anode can be summarized as follows.

(1) The degradation rates increased as the time of anode exposure to $\mathrm{PH}_{3}$ extended.

(2) The dominant form of Ni-P was $\mathrm{Ni}_{3}\left(\mathrm{PO}_{4}\right)_{2}$ both with current load and without current load when the electrolyte supported Ni/YSZ half-cell was operated in $\mathrm{PH}_{3}$ containing wet coal-syngas. For the cell operated in $\mathrm{PH}_{3}$ containing dry coal-syngas, there is no phosphorus signal detected. However, there is limitation in the time duration in our experiment. Long-term testing is needed to confirm the conclusion.

(3) Electric current facilitated the degradation of the anode. Ni migrated and agglomerated at the anode surface, blocking fuel gas diffusion to the anode inner layer. The reduction of $\mathrm{Ni}$ at inner layer also led to a loss of active TPB sites. Electric field induced electrostatic force $F_{\text {field }}$ was proposed to cause Ni migration. In addition, the chemical potential difference of phosphorus between gas phase and solids also played a significant role in Ni redistribution.

(4) The phosphorus contamination was more severe when the anode was operated in moisture condition. The deposition of surface carbon layer blocked phosphine diffusion into anode inner layer.

(5) $\mathrm{PH}_{3}$ needs to be removed from the coal-syngas to sub-ppm level by clean-up technique. Effective solutions are also suggested to mitigate Ni electromigration. 


\section{Chapter 4: Conclusions and Recommendations on Future Work}

\subsection{Conclusions}

In this work, the influence of electric current and moisture concentration on the degradation of $\mathrm{Ni} /$ YSZ anode upon exposure to $\mathrm{PH}_{3}$ has been studied. Anode half-cells operated in various conditions showed different electrochemical properties and microstructures. The results of our investigation on can be summarized as follows

(1) The degradation rates of cell's electrochemical performance accelerated as $\mathrm{PH}_{3}$ exposure time increased.

(2) The dominant form of Ni-P was $\mathrm{Ni}_{3}\left(\mathrm{PO}_{4}\right)_{2}$ both with current load and without current load when the electrolyte supported Ni/YSZ half-cell was operated in $\mathrm{PH}_{3}$ containing coal-syngas.

(3) Electric current facilitated Ni/YSZ anode degradation. Ni migrated and agglomerated at the anode surface blocking fuel gas diffusion to the anode inner layer and the reduction of $\mathrm{Ni}$ in the inner layers led to the loss of active TPB sites. Electric field induced force $\mathrm{F}_{\text {field }}$ was proposed as the cause of Ni migration and the chemical potential difference of phosphorus between gas phase and solids also plays a significant role in Ni redistribution.

(4) Phosphorus contamination was more severe when the anode was operated in moisture conditions. The deposition of surface carbon blocked phosphine diffusion into the anode inner layer. No phosphorus was detected for the anode exposure to $\mathrm{PH}_{3}$ containing dry coal syngas for 24 hours.

\subsection{Recommendations for Future Work}


$\mathrm{PH}_{3}$ in coal-derived synthesis gas has been shown to degrade Ni/YSZ anode performance. $\mathrm{PH}_{3}$ must be removed to parts per billion levels before the syngas can be used in SOFCs. An efficient technique can be developed to eliminate or mitigate the $\mathrm{PH}_{3}$ poisoning of Ni/YSZ anodes based on the degradation mechanism proposed in this work. I recommend the following studies to be done in the future:

(1) A new pre-filter for $\mathrm{PH}_{3}$ removal will be designed and fabricated.

(2) Electrochemical tests will be combined with materials characterization technique to evaluate the $\mathrm{PH}_{3}$ pre-filter performance.

(3) The durability of the pre-filter will be measured to give a quantitative guidance in industrial production. In addition, theoretical analysis will be carried out to understand the underlying mechanism for $\mathrm{PH}_{3}$ removal in the pre-filter. 


\section{References}

${ }^{1}$ Cheng Z., Wang J., Choi Y., Yang L., Lin M. C., Liu M. Energy Environmental Science.2011, 4, 4380-4409.

${ }^{2}$ Bao J., G. N. Krishnan, P. Jayaweera, K. Lau, A. Sanjurjo. Journal of Power Sources. 2009, 193, 617-624.

${ }^{3}$ Martinez A., Gerdes K., Gemmen R., Poston J., Journal of Power Sources, 2010, 195, 5206-5212.

${ }^{4}$ Baldini G.L., Munari I. De, Scorzoni A., Fantini F., Microelectronics Reliability. 1993, 33(11-12), 1779-1805.

${ }^{5}$ Jenson K.V., Wallenberg R., ChorkendorffI.,Mogensen M., Solid State Ionics. 2003,160, 27-37.

${ }^{6}$ Zhi M.J., Chen X.Q., Finklea H.,CelikI.,Wu N.Q., Journal of Power Sources. 2008, 183, 485.

${ }^{7}$ Singh P., Pederson L.R.,Simner S.P., Stevenson J.W., ViswanathanV.V. Proceedings of IECEC: 36thAnnual

Meeting, Savannah, GA, July 29, 2001.

${ }^{8}$ Jiang J.H., RyuJ.H.,Oh S.M., Ionics. 2000,6, 86.

${ }^{9}$ Liu J., Barnett S.A., Solid State Ionics.2003, 158, 11.

${ }^{10}$ John Staniforth and R. Mark Ormerod, Ionics, 2003, 9, 336.

${ }^{11}$ Trembl J. P., Marquez A. I., Ohrn T.R., Bayless D. J., Journal of Power Sources, 2006,158,263.

${ }^{12}$ Nernst W., Z. Elktrochem.,1899,6, 41-43.

${ }^{13}$ O’Hayre R. P., Cha S.W.,ColellaW. G., PrinzF. B., Fuel Cell Fundamentals $2^{\text {nd }}$ ed.; John Wiley \& Sons, New York, 2008; pp 71-75.

${ }^{14}$ RichterJ.,HoltappelsP., GrauleT., Tetsuro N., Ludwig J. G. Monatshefte fur Chemie/Chemical Monthly. 2009,140, 985-999.

${ }^{15}$ State of the World 2009, Worldwatch Institute, 2009.

${ }^{16}$ EIA, Electric Power Annual-Table 2.2.Existing capacity by energy source.www.eia.doe.gov/cneaf/electricity /epa2p2.html.

${ }^{17}$ EIA, Electric Power Monthly-Table 1.1.Next generation by energy source.www.eia.doe.gov/electricity/epm/ table 1_2.html.

${ }^{18}$ Eserven R, EssourcenR,Erfügbarkeitvon V. Energierohstoffen. 2002, BGR.

${ }^{19}$ Enerdata analyses the trends in energy demand, based on its 2010 data for G20 countries. May 5th, 2011

${ }^{20}$ Higman C.,Burgt, M.v.d., Gasification Elsevier. 2003.

${ }^{21}$ Higman C., BurgtM. v.d., Gasification Elsevier.2003.

${ }^{22}$ Ratafia-Brown J., Manfredo L., Hoffmann J., Ramezzan M., major environmental aspects of gasification-based power generation Technologies, Final Report, U.S. Department of Energy, 2002

${ }^{23}$ Trembly J.P., Gemmen R.S., Bayless D.J., Journal of Power Sources.2007,163, 986.

${ }^{24}$ Díaz-Somoano M., Martínez-Tarazona M.R., Fuel. 2003, 82,137.

${ }^{25}$ Marina OA, Pederson LR, Gemmen R, Gerdes,Finklea K. H, Celik, I.B. ECS Transactions.2010, 26(1), 363-370.

${ }^{26}$ Martinez A., Gerdes K., Gemmen R., Poston J., Journal of Power Sources.2010, 195, 5206-5212. 
${ }^{27}$ Krishnan G., Proceeding of the 8th Annual SECA Review Workshop, San Antonio, TX, 2007.

${ }^{28}$ Nielsen B., JVilladen.,Appied Catalysis. 1984, 11, 123-128.

${ }^{29}$ Quinn R., Mebrahtu T., Dahl T.A., Lucrezi F.A., Toseland B.A., Applied. Catalysis A. 2004, 264, 103-109.

${ }^{30}$ Roberts G.W., Brown D.M., Hsiung T.H., Lewnard J.J., Industrial and Engineering Chemistry Research. 1993, 32, 1610-1621.

${ }^{31}$ Air Products and Chemicals Inc., Removal of Trace Contaminants from Coal-Derived Synthesis Gas, Topical Report, U.S. Department of Energy, 2003, pp.7-23.

${ }^{32}$ Marina O. A., Pederson L. R., Coyle C. A., Thomsen E.C., Edwards D. J., Nguyen C.D., Coffey G.W., Proceedings of the 9th Annual SECA Workshop 2008 Pittsburgh, PA.

${ }^{33}$ Sasaki K., Susuki K., IyoshiA., Journal of the Electrochemical Society.2006, 153,11.

${ }^{34}$ Gong M., Liu X, Trembly J., Johnson C. Journal of Power Sources. 2007, 168, 289-298.

${ }^{35}$ Schubert S. K., Kusnezoff M., Wunderlich C. Proceedings of 8th European SOFC Forum 2008 Lucerne, Switzerland

${ }^{36}$ Liu M., Cheng Z., Choi Y., Wang J.,Zha S., Proceedings of the 7th Annual SECA Workshop and Peer Review, Philadelphia, PA, September 12-14, 2006.

${ }^{37}$ Haga K., Adachi S., Shiratori Y., Itoh K., Sasaki K., Solid State Ionics, 2008, 179, 1427-1431.

${ }^{38}$ BaoJ.,Krishnan G., Jayaweera P., Sanjurjo A. Journal of The Electrochemical Society, 2010, 157,415-424.

${ }^{39}$ Demircan O., Zhang W., Xu C., Zondlo J.,Finklea H. O., Journal of Power Sources, 2010, 195, 3091-3096.

${ }^{40}$ Baldini G.L., Munari I. De, Scorzoni A., Fantini F., Microelectronics Reliability. 1993, 33(11-12), 1779-1805.

${ }^{41}$ Jenson K.V., Wallenberg R., Chorkendorff I., Mogensen M., Solid State Ionics. 2003,160, 27-37.

${ }^{42}$ Zhi M.J., Chen X.Q., Finklea H., Celik I., Wu N.Q., Journal of Power Sources. 2008, 183, 485.

${ }^{43}$ Marina O. A., Pederson L. R., Edwards D. J., Coyle C. W., Templeton J., Engelhard M., Zhu Z.. Proceedings of the 8th Annual SECA Workshop 2007 San Antonio, TX.

${ }^{44}$ Xu C., Zondlo J., Gong M., Liu X.,Journal of Power Sources.2011, 196, 116-12

${ }^{45}$ Demircan O., Xu C., Zondlo J., Finklea H. O.,Journal of Power Sources. 2009,194, 214-21

${ }^{46}$ Channa K., Silva R. D., KasemanB. J., BaylessD.J.,International Journal of Hydrogen Energy. 2011,36, 99459955.

${ }^{47}$ Zhi M., Cayan.N.F, Celik I., Gemmen R., Pakalapati S. R.,Wu N.Q. Fuel Cell , 2010, 10,1, 174-180.

${ }^{48}$ Guo H., Iqbal G., Kang B.S. Int. J. Appl. Ceram. Technol., 2011, 8(1), 68-73.

${ }^{49}$ Coyle.A., Marina O. A., Thomsen E.C., Edwards D.J., Cramer C.D., Coffey G. W., Pederson,L. R. Journal of Power Source. 2009,173,730.

${ }^{50}$ SasakiK. , Haga K. , YoshizumiT. , MinematsuD. , YukiE. , LiuR. , UryuC. , OshimaT. , OguraT. , ShiratoriY. , Ito K. , Koyama M. , YokomotoK. , Journal of Power Sources. 2011, 196, 9130-9140

${ }^{51}$ Haga K., Shiratori Y., Ito K., Sasaki K., Journal of Electrochem. Society.2008,155, 1233

${ }^{52}$ Gemmen R., GerdesK., Hackett G., Martinez A., Proceedings of the 10th Annual SECA Workshop 2009 Pittsburgh, PA 
${ }^{53}$ Gerdes K., Trembly J., Germen R., Proceedings of the Coal Based Fuel Cell Technology: Status, Needs and Future Applications, Morgantown, WV, 2007

${ }^{54}$ Veyo S.E., Evaluation of Fuel Impurity Effects on Solid Oxide Fuel Cell Performance, Final Technical Report, Westinghouse Electric Company, Pittsburgh, 1998.

${ }^{55}$ Baldini G.L., Munari I. De, Scorzoni A., Fantini F., Microelectronics Reliability. 1993, 33(11-12), $1779-1805$.

${ }^{56}$ Jenson K.V., Wallenberg R., Chorkendorff I., Mogensen M., Solid State Ionics. 2003, 160, $27-37$.

${ }^{57}$ Marina O.A., Coyle C.A., Thomsen E.C., Edwards D.J.,Coffey G.W.,PedersonL.R.,Solid State Ionics. 2010,181, 430-440

${ }^{58}$ Franke R., Chasse Th., Streubel P., MeiselA..Journal of Electron Spectroscopy and Related Phenomenon.1991, 56,381

${ }^{59}$ Moulder J.F., Stickle W.F., Sobol P.E., Bomben K.D., Handbook of X-ray Photoelectron Spectroscopy, Physical Electronics, Eden Prairie, MN, 1995.

${ }^{60}$ John F. Moulder, William F. Stickle, Peter E. Sobol, Kenneth D. Bomben, Handbook of X-ray Photoelectron Spectoscopy, Jill Chastain, Roger C. King Jr. Editors, Physical Electronics, Japan, 1995

${ }^{61}$ Cayan 2010: 81. A phenomenological model for degradation of solid oxide fuel cell anodes due to impurities in coal syngas. Ph.D Dissertation, West Virginia University, Morgantown.

${ }^{62}$ Kishimoto H., Yamaji K., Brito M. E., HoritaT., Yokokawa H.,Journal of Mining and Metallurgy.2008, 44 B, 3948.

${ }^{63}$ Xu C., Zondlo J., Finklea H. O., Demircan O., Gong M., Liu X., Journal of Power Sources,2009, 193, 739-746.

${ }^{64}$ ZhongN., Wang X., RongY. Wang L, Journal of Material Science and Technology. 2006, 22,6.

${ }^{65}$ BasaranC, Li S, AbdulhamidM. F., Journal of Applied Physics. 2008,103, 123520.

${ }^{66}$ AoyagiaM.,J. Mater. Res.,2004,19, 8.

${ }^{67}$ Jenson K.V., Wallenberg R., Chorkendorff I., Mogensen M., Solid State Ionics.2003, 160, $27-37$.

${ }^{68}$ Guo H., Iqbal G., Kang B.S., International Journal of Applied Ceramic Technology. 2010, 7, 55-62.

${ }^{69}$ Jiao Z, ShikazonoN.,KasagiN., Journal of Power Sources.2011,196, 8366- 8376.

${ }^{70}$ Liu W., Sun X., Pederson L. R., Marina O. A., Khaleel M. A., Journal of Power Sources. 2010,195, 7140-7145.

${ }^{71}$ Perry D. L., Phillips S.L.. Handbook of inorganic compounds. CRC Press, 1995, p. 271.

${ }^{72}$ PadtureN.P.,GellM., Jordan E. H.,Science.2002,296, 280-284.

${ }^{73}$ Jang J. W., Kim P. G., Tu K. N., Frear D. R., P Thompson.,Journal of Applied Physics.1999, 85, 12.

${ }^{74}$ UdalovY. P., Lavrov B. A., Kozlov K. B., Degrave I. E., Glass Physics and Chemistry.2004, 30, $191-197$.

${ }^{75}$ Tomlinson W. J., Wilson G. R.,Journal of Materials Science.1986, 21, 97-102.

${ }^{76}$ KrishnanG., Technical progress report 1, SRI International, Morgantown, 2006. 


\section{Appendix}

\section{Appendix A: Program for porosity calculation of the surface appearance image}

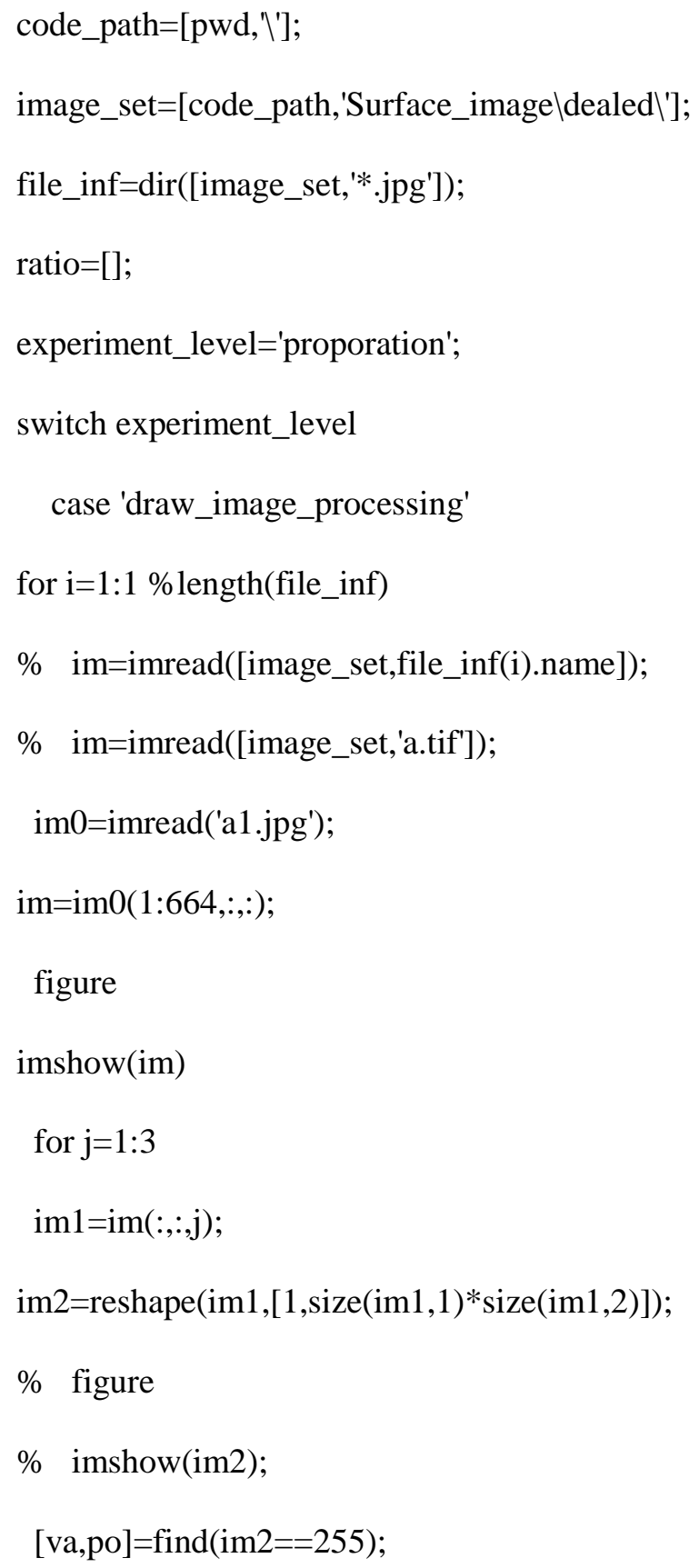




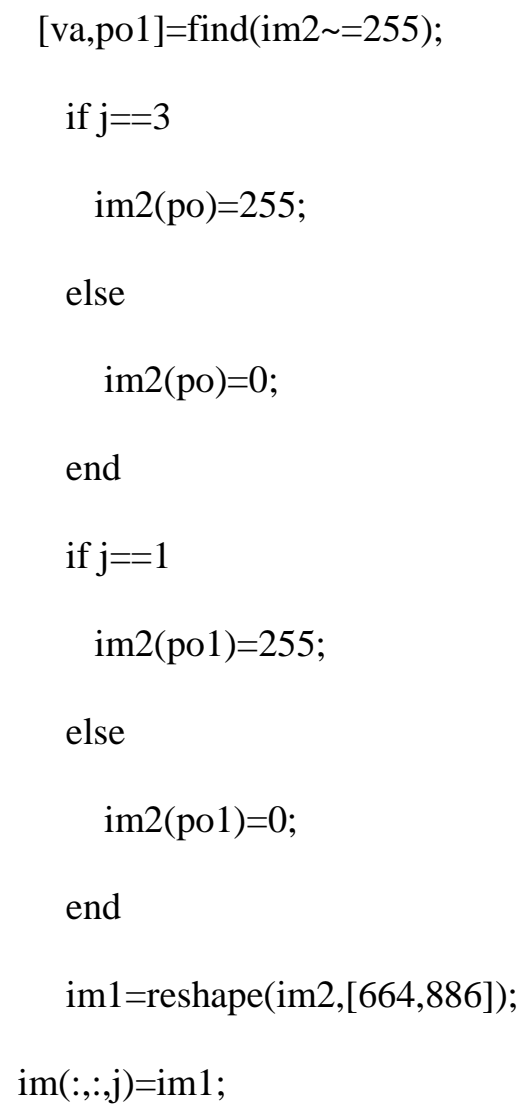

end

case 'proporation' 


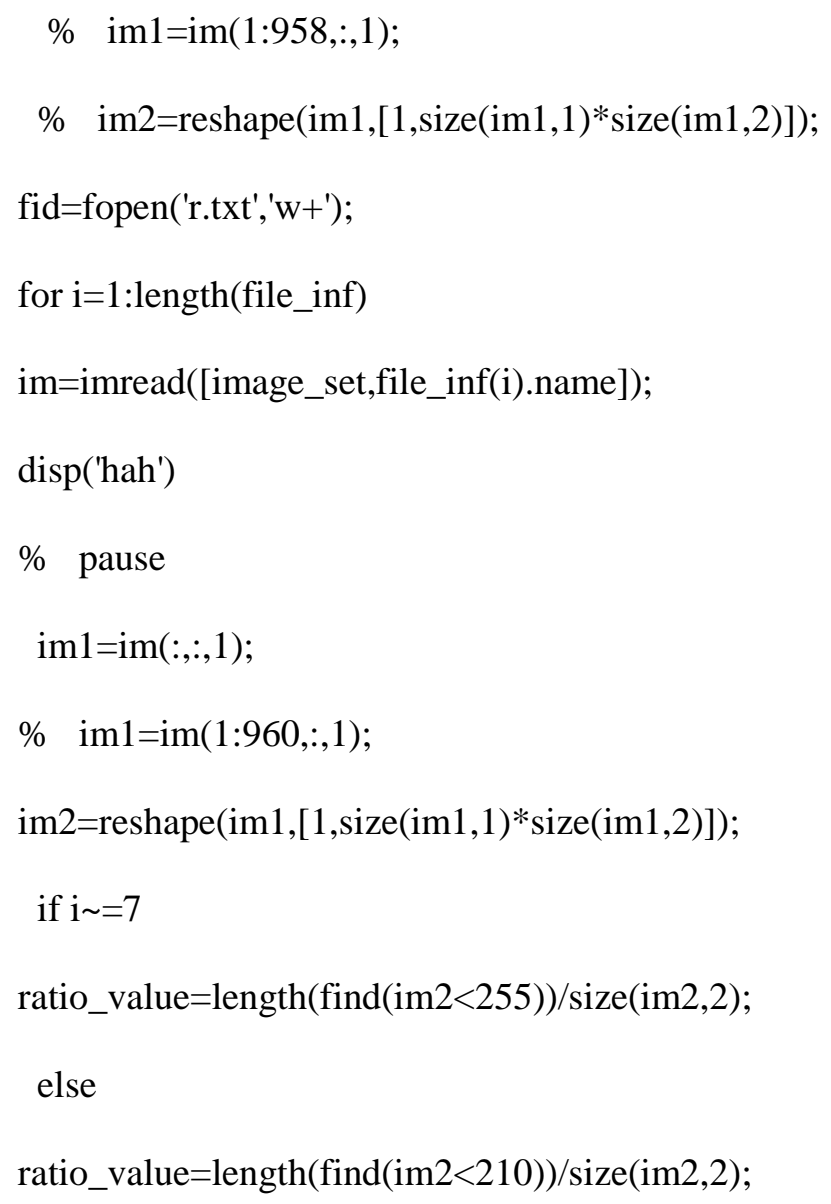

end

if strcmp(file_inf(i).name,'26.24hrs_current_1000.JPG')

ratio_value=length(find(im2<230))/size(im2,2);

elseifstrcmp(file_inf(i).name,'24.24hrs_nocurrent_1000.jpg')

ratio_value=length(find(im2<230))/size(im2,2);

elseifstrcmp(file_inf(i).name,'14hrs_current_1000.jpg')

ratio_value=length(find(im2<240))/size(im2,2);

elseifstrcmp(file_inf(i).name,'2hrs_current_1000.JPG')

ratio_value=length(find(im2<250))/size(im2,2); 
end

image_name $\{\mathrm{i}\}$.name=file_inf(i).name;

image_name $\{\mathrm{i}\}$.ratio=ratio_value;

fprintf(fid,'\%s ',num2str(i));

fprintf(fid,'\%s ',image_name\{i\}.name)

fprintf(fid,'\%s ',num2str(ratio_value));

fprintf(fid,'ไn');

end

fclose(fid);

end

\section{Appendix B: Author's publication list during master study}

\section{Peer-Reviewed Journal Papers:}

1. Jinlong Yan, Mingjia Zhi, Xinqi Chen, Savan Suri, Fanke Meng, Xiaolong Wang, Nianqiang Wu. Influence of Electric Current and Moisture Concentration on $\mathrm{PH}_{3}$ Contamination to Ni/YSZ Anode of SOFC. (to be Submitted)

\section{Presentations:}

1. Jinlong Yan*, Mingjia Zhi, Nianqiang Wu. PH3 Poisoning Effect on Ni/YSZ Cermet Solid Oxide Fuel Cell Anode. $87^{\text {th }}$ annual meeting of the West Virginia Academy of Science and the $4^{\text {th }}$ biennial STaR Symposium. Charleston, WV, Apr 21, 2012. 
2. Mingjia Zhi, Jinlong Yan, Ayyakkannu Manivannan, Nianqiang Wu. Degradation Mechanism of Nickel-Yttria Stabilized Zirconia SOFC Anode Materials in $\mathrm{PH}_{3}$ Containing Coal Syngas. 219th ECS Meeting, Electrochemical Society. Montreal, QC, Canada, 2011

3. Jinlong Yan, Savan Suri, Nick Wu. "Elemental Mapping: tracking the composition of a solid oxide fuel cell," participant in WVNano's art exhibit Imaging the Invisible, Downtown Morgantown Arts Walk. West Virginia, Oct 14, 2011. 